\title{
Ética y metafísica \\ (Una reconsideración de la cuestión) XVI Conferencias Aranguren
}

\author{
Ethics and Metaphysics \\ (A Revisitation) \\ XVI Aranguren Lectures
}

\author{
JAVIER MUGUERZA \\ UNED, Madrid
}

Resumen. En el primero de los dos grandes apartados en los que el texto se divide, se pasa revista al medio siglo de «avatares de la razón» atravesado por la ética desde los orígenes del «giro lingüístico» de la filosofía contemporánea al desafío que representa para ella el llamado «pensamiento postmetafísico» característico de la postmodernidad. Haciendo frente a este último, pero asimismo a cualesquiera intentos de restauración de la vieja metafísica premoderna, la segunda parte del texto defiende la conveniencia -0 , para ser exactos, la necesidad - de que la filosofía moral mantenga hoy su apertura a lo que se da arangurenianamente en llamar «el horizonte metafísico de la ética». Dicha apertura habría de permitir a los filósofos morales hacerse cargo tanto de «la pregunta por (las condiciones de posibilidad de) lo real» en que la ética hunde sus raíces cuanto de «la pregunta por (las condiciones de realización de) lo posible» que hermana a dicha ética con lo mejor del pensamiento utópico, así como encarar, en fin, aquellas preguntas últimas o «preguntas $\sin$ respuesta» que, desde la modernidad a nuestros días, insisten en recordarnos que el emblema de la filosofía, y por lo pronto de la filosofía moral, no es otro que el signo de interrogación.
ABSTRACT. The first of the two great sections in which the text is divided is a review of the half-century of «vicissitudes of reason» traversed by ethics, from the origins of the «linguistic turn» of contemporary philosophy right across to the challenge posed to it by the characteristically postmodern so-called «postmetaphysical thought». Confronting the latter, but dealing at the same time with any attempts at restoring the old premodern metaphysics, the second part of the text defends the convenience - or, rather, the necessityof having moral philosophy maintain its openness to what has been termed as «the metaphysical horizon of ethics», in Aranguren-style coinage. Such openness would allow moral philosophers to take on both «the question regarding (the conditions of possibility of) what is real» in which ethics is deeply rooted and «the question regarding (the conditions of realization of) what is possible» which merges the aforesaid ethics with the best of utopian thought, as well as to finally face those ultimate questions or «unanswerable questions» which, from the modern era to this day and age, insist on reminding us that the emblem of philosophy, and of moral philosophy at that, is none other than the question mark. 
Palabras clave: Ética, filosofía moral, metafísica (de la) moral; giro lingüístico; razón teórica, razón práctica; razón analítica, razón dialógica, razón comunicativa; racionalidad, razonabilidad; pensamiento postmetafísico; preguntas sin respuesta.
Key words: Ethics, moral philosophy, metaphysics of morals; linguistic turn; theoretical reason, practical reason; analytical reason, dialogical reason, communicative reason; rationality, reasonableness; postmetaphysical thought; unanswerable questions.

\section{La ética, del giro lingüístico al pensamiento postmetafísico}

\section{Aranguren y el «giro lingüístico»}

En el prólogo al libro de un por entonces joven estudioso - el hoy profesor de la Universidad de Salamanca Enrique Bonete- publicado a finales de los ochenta del siglo pasado bajo el título de La ética de Aranguren, entre la religión y la política, tuve ocasión de referirme a las materias que trataba José Luis López Aranguren en sus clases y seminarios el primer curso en que asistí con regularidad a unas y otros, aproximadamente una veintena larga de años antes. «Si no recuerdo mal» - escribía allí- «Aranguren organizó sucesivamente tres seminarios a lo largo de aquel curso: el primero de ellos versaba sobre las Ethische Untersuchungen de Husserl, que habían sido recientemente recopiladas y editadas por Alois Roth; el segundo respondía al rótulo de «Moral y marxismo» (su visión del asunto se publicaría algo después en un libro titulado El marxismo como moral) y anunciaba de algún modo la discusión que acabaría enzarzando en breve a marxistas humanistas y althusserianos; y el tercero, en fin, se dedicaría a comentar el libro de Richard Hare The Language of Morals, asimismo aparecido hacía escasos meses». Era así - subrayaba yo a continuación - como en aquella Facultad de Filosofía de la Universidad Central posteriormente mal llamada Complutense, retrogradada a la sazón a la Edad Media, los estudiantes nos dábamos de bruces con los tres grandes paradigmas filosóficos del momento (la fenomenología, el marxismo y la filosofía analítica) en la más viva actualidad de todos ellos por lo que a la ética concernía.

Aun si preferentemente implantado en la última de las corrientes mencionadas, es decir, la filosofía analítica, el llamado «giro lingüístico» de la filosofía contemporánea acabaría extendiéndose a las otras dos, la fenomenología y el marxismo, siquiera sea a través de sus respectivas áreas de influencia (como la hermenéutica, la teoría crítica de la Escuela de Francfort o los diversos estructuralismos y post-estructuralismos), produciéndose así lo que hubo de llamarse la generalización del giro lingüístico, el cual hegemonizaría por muchos años el pensamiento filosófico hasta llegar a nuestros días: Aranguren se hallaba al tanto del fenómeno en los dominios de la Ética, tal y como su colega el filósofo exiliado José Ferrater Mora, con quien le unía estrecha 
amistad, lo estaba en los de la Filosofía en general, circunstancia que habría de permitirles contribuir decisivamente a su divulgación y su cultivo entre nosotros casi a la par que la hegemonía del giro lingüístico se fue extendiendo y afianzando a nivel mundial.

Ya que no la acuñación de la expresión «giro lingüístico» — que se debió en rigor a Gustav Bergmann, miembro actualmente no muy recordado de lo que fue en su día el Círculo de Viena-, su difusión se suele atribuir a un joven Richard Rorty a través de la bien conocida antología suya de textos metafilosóficos precisamente titulada The Linguistic Turn (1967). Con el paso del tiempo, Rorty fue amortiguando su un día positiva valoración de la importancia filosófica de dicho giro. Y, ya en su madurez, llegaría incluso a proclamar - en un alarde de la reconocida capacidad de provocación que siempre le caracterizó- que el giro lingüístico se había reducido a fin de cuentas a «una tempestad en la tetera académica» (a storm in the academic teapot).

Pero no adelantemos acontecimientos y, dejando por el momento a un lado a Rorty, detengámonos a intentar hacer a grandes rasgos lo que orteguianamente cabría llamar tal vez «balance y perspectiva» del susodicho giro.

\section{Medio siglo de avatares de la razón}

En otro lugar que no hace al caso mencionar ahora, me he referido al giro lingüístico de la filosofía caracterizándolo como «un avatar de la razón», esto es, como una fase o una vicisitud de la historia de la razón, «fase» o «vicisitud» (que es como el Diccionario de la Lengua describe un «avatar») susceptible en cuanto tal de encuadrarse dentro de un avatar más amplio (dentro del marco, por ejemplo, de la razón moderna e ilustrada) y susceptible asimismo de subdividirse en tantos otros avatares menores como episodios - es decir, fases o vicisitudes - nos sea dado distinguir dentro del mismo.

Veámoslo con algún mayor detalle comenzando por la razón moderna, o propia de la Modernidad, a la que hemos descrito como a su vez otro avatar histórico de la racionalidad, un término ése que — además de la definición de uso que recogíamos en el Diccionario («avatar» como fase o vicisitud temporal) - presenta una etimología notablemente digna de atención puesto que remite nada menos que al sánscrito, donde el vocablo auatar (o auatara) servía en la tradición religiosa hindú para designar a las diversas «encarnaciones»o manifestaciones posibles de una divinidad (como cuando en el hinduísmo se dice hoy todavía que Rama, Krishna o Kali son otros tantos avatares del dios Visnú). Y la alusión a la divinidad no es aquí excéntrica u ociosa, ni traída tampoco por los pelos, sino viene precisamente muy a cuento de ese apogeo de la Ilustración representado por la Revolución Francesa. En el curso de esta última, en efecto, se llegó a instituir como es sabido —el 20 de Brumario de 1793 y en el contexto del Decreto que proclamaba en Francia la libertad de cultos - nada menos que el culto a la diosa Razón, a la cual el Ayuntamiento 
de París dedicaría un templo (conocido como «Templo de la Razón») previa incautación de la Iglesia metropolitana de Nuestra Señora (Notre Dame, claro) que, una vez convertida en edificio republicano, acogería actos litúrgicos tales como la pública lectura los domingos del Acta Constitucional por la mañana y la Declaración de los Derechos del Hombre y del Ciudadano por la tarde (¡lo que se dice un buen plan familiar para disfrutar de una vacación dominical!).

$\mathrm{Y}$, sin alcanzar el pintoresquismo de esos extremos, lo cierto es que en la Francia de la época no era infrecuente ver escrita con mayúscula la palabra Raison en los textos de algunos ilustrados, que es lo más cerca de la deificación que le es dado llegar a la ortografía en el ámbito de la escritura. Comoquiera que sea, y dado que en nuestra lengua no contamos con recursos prosódicos que nos permitan enfatizar una palabra elevando la entonación de nuestra voz, nosotros mismos no tendremos otro remedio que acudir a la $m a-$ yúscula (o, en el discurso hablado, a la expresión «la Razón con mayúscula») cuando queramos dar a entender el énfasis con que este o aquel filósofo invoca, trata o recurre a la razón, cosa que no es posible hacer, en cambio, con una lengua como la alemana donde todos los sustantivos se escriben con mayúscula. A no ser que disparatemos, como le oí un buen día a cierto ilustre comilitón que peroraba sobre la racionalidad, o lo que él entendía por tal, encomiando al respecto a Kant en gracia a la veneración prestada a la razón, a la Vernunft, al escribirla siempre de tan respetuosa guisa y nunca jamás por el contrario con minúscula...

Pero, en fin, no trivialicemos nuestra aproximación a la razón moderna e ilustrada, ese importantísimo avatar de la razón que en rigor constituye el humus sobre el que necesariamente han de arraigar cualesquiera otros avatares de la razón que hayan podido materializarse desde la Ilustración acá. ¿Qué fue, o qué quiso ser, semejante Ilustración? Como tantas veces le ha sido reconocido, nadie supo encarar esa cuestión mejor que Kant lo hizo en su texto de 1784 «¿Qué es la Ilustración?» (Was ist Aufklärung?).

«La Ilustración» — se respondía Kant a sí mismo- «es la liberación del hombre de su culpable minoría de edad. Esta minoría de edad significa la incapacidad de servirse de su inteligencia sin la guía de algún otro. Y uno mismo es el culpable de dicha minoría de edad cuando su causa no reside en la falta de inteligencia sino en la falta de decisión y de valor para servirse de ella sin la tutela ajena. Sapere aude! Atrévete a saber, esto es, ten el valor de servirte de tu propia razón. He aquí el lema de la Ilustración».

La Ilustración fue ante todo un acto de confianza en sí misma de la razón humana $y$, por ende, vino también a constituir uno de esos momentos estelares de la historia de la humanidad en los que ésta se atreve a acariciar el sueño de la emancipación. La emancipación, por lo pronto, de los prejuicios y las supersticiones que a nivel teórico atenazaban a la razón humana (comenzando, en primerísimo lugar, por ese prejuicio o esa superstición en que consiste 
«el miedo a la razón»), pero también, a nivel práctico, la consiguiente emancipación de las tiranías con que («contra toda razón»o, por lo menos, contra aquella razón tenida por liberadora) los diversos poderes de este mundo han oprimido a los seres humanos una vez y otra a lo largo de su agitada historia: retengamos de todo ello para más adelante que la razón, como hemos visto, opera a dos niveles que dan lugar a otros tantos usos de la razón (a los que Kant llamó su «uso teórico» y su «uso práctico» o — si lo preferimos decir así- la «razón teórica» y la «razón práctica», terminología que no es exactamente la kantiana pero puede servir mejor hoy día para entendernos). Y, tanto a un nivel como a otro, el sueño ilustrado de la emancipación, esto es, el sueño de la liberación de la humanidad erigido en promesa por la Ilustración, fue como alguna vez se le ha llamado el sueño de la razón.

Y si pensamos ahora, como yo mismo he invitado a hacerlo en más de una ocasión, en el soberbio grabado de Goya que el pintor rotuló con la leyenda «El sueño de la razón produce monstruos», tal vez nos ponga ello en la pista de explicarnos en qué estriba esa crisis de la razón moderna por antonomasia que era «la razón ilustrada», crisis que —en el transcurso de los últimos cincuenta años de que nos toca ahora ocuparnos - ha venido a desembocar en lo que se ha dado en llamar la «Postmodernidad»o, lo que viene a ser lo mismo, la «Postilustración».

Como se recordará, en el grabado de Goya un hombre duerme - acodado sobre su mesa de trabajo, la mesa, diríamos hoy, de un intelectual (de un philosophe, como se hubiera dicho en el siglo XVIII) - mientras, en la penumbra de la estancia, le rodean y le sobrevuelan una serie de monstruos, los monstruos que se suponen producidos por el sueño de la razón. ¿Cómo interpretar el grabado de nuestro pintor? De entre las numerosas interpretaciones que se han dado del mismo, vamos a seleccionar tres que se inspiran (aun si reinterpretadas por mi parte con el fin de adaptarlas a nuestros propósitos) en las de un par de buenos amigos como lo son el profesor español José Enrique Rodríguez Ibáñez - en su libro de los años ochenta El sueño de la razón: la modernidad a la luz de la Teoría Social - y el profesor alemán Volker Rühle en la Introducción a su antología Beiträge zur Philosophie aus Spanien de los noventa.

En una primera interpretación del grabado de Goya - que podríamos calificar de premoderna y por ende de preilustrada, si es que no incluso de contrailustrada - los monstruos que pueblan el grabado habrían de ser atribuidos al delirio racional del hombre, es decir, a su olvido de las sanas doctrinas de la tradición y a su atrevido intento de ponerse a pensar, esto es, a soñar por cuenta propia. En cambio, para una segunda interpretación que merecería ahora el calificativo de plenamente moderna e ilustrada - y que es, con toda probabilidad, la que el propio pintor habría hecho suya- los monstruos en cuestión serían producto no de la ensoñación o el sueño activo, sino del sueño pasivo de la razón humana, cuyo perezoso dormitar habría dejado abierta la espita de las tinieblas del oscurantismo y dado así lugar a la invasión por ellas 
de la estancia. Pero cabe aún una tercera interpretación posible de nuestro grabado a la que no sería del todo improcedente ver calificada de postmoder$n a$ o de postilustrada y de acuerdo con la cual la capacidad de soñar activamente, más bien que dormir pasivamente, de una razón ambiciosa en demasía - la Razón que algunos ilustrados tendían a deificar, no vacilando según vimos en escribirla con mayúscula - se pudo acabar volviendo, paradójicamente, contra los mismísimos postulados iluministas y emancipatorios que en sus orígenes la alentaron, para pasar luego a aherrojarla con la cadena de nuevas e impensadas formas de esclavitud del calibre de Auschwitz, el Gulag o Hiroshima, por no citar sino tres muestras de veras antonomásticas.

Pero, volviendo a Kant, ¿por cuál de esas tres interpretaciones del grabado se habría éste inclinado en caso de haber podido llegar a conocerlo? En un cierto sentido, el ilustrado que fue Kant habría adherido sin reservas a la segunda de ellas, esto es, a la interpretación que justamente llamamos antes ilustrada. Y en ningún caso lo habría hecho con la primera o preilustrada, contrailustrada y lisa y llanamente reaccionaria a secas. Pero, y esta sería una prueba de la indudable actualidad de Kant pese a los dos siglos transcurridos tras su muerte, desde su posición no le habría estado en rigor vedado hacerse cargo de la tercera. Es decir, de la interpretación que dimos antes en llamar postmoderna o postilustrada, lo que diferenciaría a Kant de esos impenitentes optimistas que, frente a aquel precursor suyo que fue Rousseau, vendrían a ser no pocos de los enciclopedistas franceses, desde Diderot a Condorcet pasando matizadamente por el propio Voltaire.

Para muchos ilustrados de semejante persuasión, la evidencia de un progresivo desarrollo de la racionalidad humana no ofrecía resquicio alguno a la duda, lo que les inducía a mostrarse absolutamente seguros de que el Hombre - un Hombre al que asimismo deificaban en ocasiones, escribiéndolo de nuevo con mayúscula - alcanzaría algún día en su plenitud los que habría llamado Kant «los fines esenciales» de la razón humana, a saber, el conocimiento exhaustivo del mundo natural y la perfecta ordenación de nuestra praxis dentro de ese mundo. $\mathrm{O}$, dicho de otro modo, aquellos ilustrados se hallaban convencidos de que el referido progreso de nuestra racionalidad no se daría tan sólo en el orden de la razón teórica (el progreso innegable de la ciencia y la técnica, por mencionar un par de instancias señaladas) sino no menos en el orden de nuestra razón práctica, llamada a registrar, a tenor de ello, un progreso moral parejo al científico-técnico cuando no impulsado por este último. $\mathrm{Y}$ es semejante fe - la fe en un progreso parigual de ambos órdenes de racionalidad, supuestamente armonizables por encima de su diversa condiciónla que parece haberse cuarteado con la postmodernidad o, por mejor decirlo, llamamos justamente «postmodernidad» al cuarteamiento de la mencionada fe en la razón, tanto si escrita ahora con mayúscula cuanto si escrita incluso con minúscula pero irremisiblemente lastrada, en cualquier caso, por la disarmonía de aquellas sus dos grandes manifestaciones. 
El postmoderno sería, entonces, aquél que desconfía de tal progreso, o lo pone en duda, o lo somete a un suspicaz cuestionamiento. Y sería hoy difícil - a menos de ser ingenuos o, todavía peor, a menos de ser cínicos- no compartir con él la suspicacia, la duda y la desconfianza. De donde no se sigue, sin embargo, que tengamos por ello que hacer nuestras el resto de las actitudes, teóricas o prácticas, del postmodernismo, según habremos de apuntar más adelante.

Por el momento, y a título no más que de advertencia, bastará con que hagamos nuestro el lema que parece inspirar el título de una obra del poeta contemporáneo Marc Strand y se diría pintiparado para prevenir las perturbaciones provocadas por el sueño de la razón, a saber, el lema que recomienda Sleeping with one eye open, esto es, «Dormir (y hasta soñar) cuanto queramos, mas siempre que lo hagamos con un ojo abierto cuando menos»...

Pero todavía antes de intentar hacernos cargo del reto postmoderno, convendría preguntarse qué es lo que ha cambiado, de Kant a nuestros días, en el modo de plantearnos la cuestión de la racionalidad. En principio, la distinción entre los usos teórico y práctico de la razón - la distinción, como hoy diríamos, entre la racionalidad teórica y la práctica (así como entre sus respectivas estofas) - se ha mantenido a grandes rasgos tal como Kant la estableció. La razón teórica opera con lo que suele conocerse bajo la denominación de juicios de hecho, como el juicio que nos informa de un cierto hecho, supongamos un hecho histórico, por medio de una afirmación en la que se nos dice que «Bruto mató a César», afirmación que en cuanto tal no incluye valoración alguna, ni positiva ni negativa, de ese hecho, pero sí admite en cambio ser conceptuada como verdadera o falsa según que se haya o no producido el hecho afirmado, esto es, según que sea o no cierto que Bruto mató a César. Y a diferencia de la razón teórica, la razón práctica, por el contrario, acostumbra a operar con juicios de valor que de ordinario se dejan resolver en juicios normativos como, pongamos por caso, ocurre con los juicios de Plutarco cuando sostiene que «Bruto llevó a cabo un acto de justicia» (o, si lo preferimos, que «Bruto hizo lo que debía» al matar a César), juicios que habría que contrastar con los de Dante, por ejemplo, cuando a su vez éste sostiene que «Bruto cometió un crimen injustificable» (o, si lo preferimos, que «Bruto no debería haber hecho lo que hizo» matando a César). En la medida en que esos juicios normativos (olvidémonos en lo que sigue de los valorativos) no refieren al mundo fáctico como los juicios de hecho, no hace al caso preguntarnos por su verdad o por su falsedad, toda vez que la normatividad no apunta tanto a lo que de hecho el mundo sea cuanto a lo que juzgamos que debiera ser, constituyendo así idealmente un mundo normativo cuya preservación exigía Kant y cuyo eclipse a lo largo de una considerable parte del siglo XX - el eclipse, en definitiva, de la ética - tuvo sin duda algo que ver, sea como causa o como efecto, con la proliferación de aberraciones por el estilo de las antes mentadas de Auschwitz, el Gulag o Hiroshima. Aberraciones to- 
das ellas susceptibles de ser catalogadas como sueños perversos (y, en definitiva, pesadillas más que sueños) de la razón. Ahora bien, si la distinción entre razón teórica y razón práctica no ha cambiado gran cosa, según acaba de decirse, de Kant a nuestros días, sí que ha cambiado, y mucho, el escenario donde hoy representar tal distinción.

Y ese nuevo escenario de la razón no es otro, como se habrá ya adivinado, que el tantas veces mentado giro lingüístico de la filosofía contemporánea. Para ser exactos, dicho giro es en rigor bastante más antiguo que todo eso y sus pioneros - como Herder o Humboldt, e incluso Hamann antes que ellos - se habrían movido todos, durante la segunda mitad del siglo XVIII y la primera mitad del XIX, en los círculos próximos, sea por acción o por reacción, a la influencia de Kant, quien sin embargo no dio muestras por todos los indicios conocidos de haber reparado en la importancia filosófica del lenguaje. Mas comoquiera que ello sea, y según ya se dijo con anterioridad, la expresión «giro lingüístico» hubo de verse consagrada gracias al título (inspirado, como asimismo recordamos, en su uso incidental por parte de Gustav Bergmann) de aquella temprana antología rortyana, sobre la que aún habremos de volver dentro de un rato, surgida en el contexto de la considerada filosofía lingüística por excelencia del siglo Xx, es decir, la autodenominada «filosofía analítica» que a sí misma se atribuyera la tarea de cultivar sistemáticamente el «análisis del lenguaje» como la vía privilegiada, por no decir la vía sin más, para la indagación filosófica. Como igualmente anticipábamos, no quería eso decir que la filosofía analítica hubiese monopolizado dentro de dicho giro el interés filosófico por el lenguaje, el cual acabaría siendo compartido - tanto con el permiso de los filósofos analíticos cuanto sin él, e incluso contra su explícita oposición- por la práctica totalidad de las corrientes filosóficas contemporáneas. Y la explicación de tal fenómeno descansa, como tantas veces ha sido subrayado, en la bien conocida anfibología del vocablo griego lógos, que lo mismo habría de poder servir para designar al lenguaje que para designar a la razón, según han insistido en resaltarlo los últimos avatares de la misma a que habremos de referirnos a continuación.

Dada su condición de avanzadilla, quizás convenga comenzar, así pues, por la filosofía analítica, aunque sea a título no más que introductorio y tomando por referencia a quien se suele hacer pasar por la figura más representativa de dicho estilo de pensar, a saber, el filósofo de estirpe kantiana Ludwig Wittgenstein, en rigor mucho más que un filósofo analítico aunque aquí tan sólo lo abordaremos bajo esa advocación, desde su primera gran obra — su famosísimo Tractatus Logico-Philosophicus aparecido en 1922 - a la segunda y última de las programadas por él mismo para su publicación, sus Philosophische Untersuchungen o «Investigaciones filosóficas» editadas póstumamente en 1954, al cabo de un par de años tras su muerte. De Wittgenstein se ha podido decir que fue el filósofo más influyente de todo el si- 
glo XX, título que tan sólo le disputaría otro filósofo de muy distinto signo aunque asimismo inmerso, como él, en el giro lingüístico. Me refiero por descontado a Martin Heidegger, cuya incursión en dicho giro nadie discute hoy día y ha sido bien documentada por algunos comentaristas perspicaces de su pensamiento, de entre quienes no quiero dejar de mencionar a Cristina Lafont y su excelente libro Sprache und Welterschliessung («Lenguaje y apertura del mundo») - cuya versión española de 1997 lleva como subtítulo el de «El giro lingüístico de la hermenéutica de Heidegger»—, pese a todo lo cual aquí no nos referiremos a este último habida cuenta de que, cualquiera que sea el grado de profundidad de la inmersión heideggeriana en nuestro giro, su influencia dentro del mismo no admite parangón con la de Wittgenstein.

Prosiguiendo con nuestro tema, y por ordenar la evolución de la filosofía analítica - incluido dentro de ella el pensamiento wittgensteiniano- con una periodización análoga a la que, paralelamente, vendría a seguir la lingüística contemporánea, cabría decir que en un primer momento los filósofos analíticos se interesaron ante todo por ese esqueleto del lenguaje que son las relaciones sintácticas entre sus signos; que pasaron después, en una segunda fase, a interesarse por el sistema nervioso del lenguaje representado por las relaciones semánticas entre esos signos y sus significados; y que concluyeron al fin por extender dicho interés, y prestar atención de tal manera, a las relaciones entre los signos en cuestión y sus usuarios, así como a los de éstos entre sí y con su contexto, es decir, a las relaciones pragmáticas a través sólo de las cuales cobra el lenguaje cuerpo entero, completándose de este modo el cuadro de conjunto de esa disciplina que se había venido dando a conocer sobre la marcha como Semiótica o «Teoría de los signos», subdividida a su vez en las tres grandes ramas que responden a las respectivas denominaciones ya clásicas de Sintaxis, Semántica y Pragmática.

Y el eje en torno al cual habría de desenvolverse esta última evolución resultó no ser otro que el creciente reconocimiento del papel del lenguaje como «medio de intercomunicación», de suerte que semejante transición desde la «sintaxis» a la «pragmática» pasando por la «semántica» — la transición, en resumidas cuentas, que discurre desde el Tractatus a las Investigaciones wittgensteinianas - llevaría a la filosofía analítica a interesarse por las funciones comunicativas del lenguaje (lo que no necesariamente implica contrariar a Chomsky, para quien es sabido que el lenguaje no se reduce con prioridad a comunicación sino antepone a ella la expresión del pensamiento, bien que de modo tal que - al expresarlo - no puede en rigor por menos, y también, de comunicarlo, que vendría a ser lo que acontece cuando del plano de la «competencia» pasamos al de la «actuación» lingüística).

Ahora bien, la corriente filosófica que mayor partido ha extraído de semejante reconocimiento del lenguaje como comunicación no ha sido tanto la filosofía analítica cuanto la hermenéutica — propensa a interesarse, como su nombre indica, por la «interpretación» (la hermenéia) del lenguaje más bien 
que por su «análisis»—, corriente ésta o conjunto de tendencias dentro de la cual ha cobrado singular importancia una determinada orientación de la misma, como la de Karl-Otto Apel, que no desdeña la colaboración con una cierta teoría crítica - como la del representante de la Escuela de Francfort Jürgen Habermas - presta a complementar la interpretación del lenguaje con una «crítica ideológica» de sus funciones e interesada en discernir entre aquella función del lenguaje que se aplica a facilitar la mutua «comprensión» de sus usuarios y aquella otra, no menos importante sea para bien o para mal, tendente a potenciar su puesta al servicio de la «dominación» unos por otros de tales usuarios.

Para citar un solo ejemplo, pero un ejemplo relevante, de cómo habría de operar semejante combinación de hermenéutica y crítica ideológica de las funciones del lenguaje, pensemos que - de acuerdo con la bien conocida clasificación de los «actos de habla» (speech acts) de Austin y Searle- se destinarían a propiciar la dominación aquellos actos de habla o «proferencias» cuya «fuerza perlocucionaria» (esto es, su capacidad de influir en la conducta ajena) ha de imponerse a cualquier otra consideración, por lo que tales actos no tendrían más objetivo que mover a la acción a nuestros interlocutores, orientándose así con exclusividad al «éxito» en la consecución de tal propósito (un acto de habla de este tipo - por ejemplo, una orden que, en un contexto militar, ordena disparar a un pelotón de fusilamiento gritando «iFuego!»— será siempre, según Habermas, erfolgsorientiert, esto es, «orientado al éxito»), mientras que una norma moral hará siempre hincapié de modo preferente en su «contenido locucionario», tratando así de convencer al interlocutor de turno sobre la base de un asentimiento comunicativamente logrado a través de la «comprensión» de dicho contenido (el contenido, por ejemplo, de la norma moral que dice «No se debe matar a un semejante»), de suerte que un acto de habla de este tipo será siempre, de nuevo según Habermas, verständigungsorientiert, esto es, «orientado a la comprensión» por la vía de la comunicación (según reza un revelador pasaje de su obra Theorie des kommunikativen Handelns, «Teoría de la acción comunicativa», de 1981).

A esta combinación de hermenéutica y teoría crítica representada por la colaboración entre ambos filósofos, Apel y Habermas, se deberá la instauración - dentro del giro lingüístico - de un nuevo avatar de la razón llamado a suceder al corporizado por la razón analítica, avatar este nuevo que se conoce de ordinario bajo el nombre de «razón (reduplicativamente, digamos) comunicativa», asimismo llamada, como haremos nosotros, la razón dialógica.

En cuanto tal, dicha razón dialógica habría heredado de la Modernidad el énfasis de ésta en la autonomía del ser humano como sujeto de la razón y por ende, asimismo, sujeto del lenguaje, de acuerdo con la ya aludida anfibología del vocablo lógos. Pero si sólo se tratase de eso, la teoría contemporánea de la razón dialógica, apeliana y habermasiana, remitiría directamente y sin intermediarios a ese otro más remoto precedente suyo que era la racionalidad 
griega (la racionalidad ejemplificada, de manera eminente, en los Diálogos socráticos de Platón). Y si la enfocáramos exclusivamente a la luz de tal genealogía - que no hay por qué recusar, dado que la razón moderna misma, y no tan sólo la dialógica, es también heredera de esa racionalidad griega- nos privaríamos de apreciar la indiscutible contemporaneidad de la teoría de la razón dialógica tal como Apel y Habermas la conciben. Pues, en efecto, su destinatario no será tanto ya el sujeto moderno a quien se dirigía la intimación del sapere aude! (en un Siglo de las Luces en el que éstas podían aún coexistir, a fin de cuentas, con el Dios del universo cristiano que todavía extendía sobre él su Providencia según Kant), sino un sujeto ahora consciente de la orfandad en la que nietzscheanamente le ha sumido la muerte de semejante Dios, esto es, su desaparición crepuscular de nuestro horizonte cultural. Y la teoría contemporánea de la razón dialógica se nos muestra por cierto plenamente dispuesta a hacerse cargo de un acontecimiento de esa índole... que deja enteramente en nuestras manos la responsabilidad por la suerte del mundo que antes se encomendaba a Dios.

Una responsabilidad esta última que se halla a la base del redescubrimiento de la relevancia filosófica del diálogo al margen, o con independencia, de sus por otra parte innegables raíces griegas sobre las que más adelante habremos de volver a insistir.

Como alguna vez se ha recordado a este respecto, para un Ser como Dios - capaz de conocer la verdad en sí y de querer por sí el sumo bien - el discurso racional, en caso de necesitarlo, podría muy bien ser un monólogo. Pero, a diferencia de Dios, el ser humano precisa del diálogo con otros seres humanos para acordar con ellos lo que entender por «verdad» y «bien»... al menos si se trata de hombres con minúscula y no del Hombre con mayúscula antes atribuido a una cierta Ilustración, por no hablar del Superhombre con posterioridad llamado a suplantar a semejante Dios o cualesquiera otros dioses tras su ocaso. Detengámonos, pues, a examinar ambos problemas —el problema de la verdad y el problema del bien- desde la perspectiva del giro lingüístico en la que ya sabemos que se enmarca dicha teoría de la razón dialógica.

Si como lo quería el llamado «primer Wittgenstein», el Wittgenstein del Tractatus, sólo hubiera un lenguaje isomórficamente acoplable al mundo - como lo vendría a ser por excelencia el lenguaje lógicamente impecable de la ciencia-, se desprende que podría hablarse de «verdad» en la medida en que haya una correspondencia entre el mundo y su representación lingüística, esto es, entre la realidad y el lenguaje. Cuando lenguaje y realidad se correspondan de una manera unívoca, de modo que aquél constituya una fiel reproducción de ésta, tendría que ser entonces fácil decidir, por ejemplo, si una teoría científica es «verdadera» o no lo es. ¿Pero qué es lo que ocurriría si no hubiese nada a lo que poder llamar «el» lenguaje y en su lugar tuviésemos multitud de lenguajes diferentes, cada uno de los cuales impusiera versiones 
asimismo diferentes de eso que antes llamábamos «la» realidad? El denominado «segundo Wittgenstein», el Wittgenstein de las Investigaciones, fue pionero en adelantar tan inquietante sugerencia, acompañada de la sugerencia - que debería ya resultarnos familiar - de que lo esencial para poder hablar de un «lenguaje» es que la actividad en que consiste éste sea compartida por los miembros de una comunidad, la comunidad de quienes lo usan y alcanzan a comunicarse mediante él. En cuanto a la filosofía contemporánea de la ciencia, parecería haber acogido con avidez ambas sugerencias, cuidando sólo de calificar a la comunidad de marras como «comunidad científica» y reemplazando el término «lenguaje» por «teoría», «constelación de teorías»o - como vendría a ser de uso común - «paradigma científico». Lo que aún es más, dicha filosofía de la ciencia se apresuró a extraer de tales sugerencias las consecuencias pertinentes, no menos inquietantes en rigor que las sugerencias mismas, puesto que si la relación entre lenguaje y realidad fuese multívo$c a$ y los lenguajes en plural - lejos de limitarse a reproducir pasivamente la realidad tal cual ésta es - contribuyesen activamente a configurarla y hasta de algún modo a producirla, se haría incluso difícil decidir cuándo una teoría es «más» o «menos» verdadera que otra. Y ni siquiera cabría echar mano aquí de la «observación empírica» con la que los positivistas de toda condición han acostumbrado a zanjar la cuestión de la verdad como correspondencia entre nuestras afirmaciones y los hechos observados, pues — como recordara alguna vez el historiador de la ciencia Thomas Kuhn - donde los aristotélicos veían un cuerpo balanceándose al extremo de una cuerda, Galileo veía un péndulo; y Lavoisier veía oxígeno donde químicos como Priestley creían ver aire deflogisticado y otros acaso no conseguían ver nada.

Y algo muy semejante a esto que ocurre en los dominios de la razón teórica vendría a ocurrir en los dominios de la razón práctica, en los que un «código» moral funcionaría de modo semejante a un «paradigma» científico (el primero, no menos que el segundo, consistiría también en un «lenguaje», aunque como sabemos ya integrado por imperativos, por normas y por juicios de valor en lugar de por enunciados o por juicios de hecho) y la discusión racional entre diversos códigos morales respecto de lo que entender por «bien» en cada uno podría ser más difícil todavía que entre diversos paradigmas científicos, como los que veíamos protagonizar la discusión entre la teoría aristotélica del movimiento y la de Galileo o entre la química priestleyana del flogisto y la de Lavoisier.

Cuando al segundo Wittgenstein le preguntaron sus discípulos un día, a propósito del ejemplo que trajimos hace un instante a colación, si la razón acerca de la muerte de César a manos de Bruto la tenían Plutarco o Dante, aquél tan sólo pudo responder que para saberlo habría que ser capaz de meterse en la piel de ambos a la vez, cosa que desgraciadamente no era posible hacer, como tampoco le parecía posible comparar entre sí distintos «juegos de lenguaje» (Sprachspiele, language-games) doblados de otras tantas y asimis- 
mo distintas «formas de vida» (Lebensformen, ways of life), como vendrían a serlo las correspondientes a la moral de la antigua Roma republicana revivida bajo el Imperio (en que se hallan insertas las Vidas paralelas de Plutarco) o a la moral de la Italia del cristianismo medieval (desde la que escribe Dante, en los albores del Renacimiento, su Divina Comedia).

Todo lo cual, repito, es inquietante, puesto que da la impresión de conducirnos desde una concepción de la verdad o el bien como instancias absolutas a una reelaboración aparentemente relativista de ambos conceptos y hasta parece poner en entredicho el papel de la racionalidad tanto científica como ética, dado que - si no hubiera modo de atar cabos a tal respecto- no habría tampoco modo de esquivar el «todo vale» al que frecuentemente parecen abocar los postmodernos.

Por lo demás, no se me oculta que el debate entre la concepción absolutista y la relativista de la verdad y el bien pudiera reducirse en demasiadas ocasiones a una de aquellas rancias «batallas entre romanos y cartagineses» con las que se acostumbraba a escenificar cualquier certamen académico en los colegios de mi remota niñez. Pero la amenaza del relativismo, en cualquier caso, continúa siendo en nuestros días merecedora de ser tenida en cuenta por la filosofía. Como también lo viene siendo, hasta llegar de vez en cuando a la obsesión, por parte de la teología, si es que hemos de hacer caso de los pronunciamientos sobre el mismo de la Iglesia Católica, desde el Papa Ratzinger a nuestra Conferencia Episcopal. Con todos mis respetos, sin embargo, no acabo de estar seguro de que el mejor modo de afrontar el secular dilema del relativismo y el absolutismo consista en abrazar sin más ni más uno de los dos cuernos, ambos indeseables, del dilema mismo. Y de ahí que prefiera otros abordajes más propiamente filosóficos del asunto, como las ponderadas «críticas del relativismo» emprendidas por una serie de filósofos contemporáneos que discurren desde Charles Taylor a nuestro compatriota Antonio Valdecantos, pasando, como aquí nos interesa, por esos dos teóricos de la razón dialógica que eran Apel y Habermas, con quienes, como vemos, proseguimos encontrándonos.

Frente a la concepción tradicional de la verdad y el bien, esto es, frente a su concepción trascendente y extralingüística, la teoría de la razón dialógica vendría por el contrario a sustentar lo que cabría llamar ahora una concepción intralingüistica de nuestros dos conceptos, es decir, una concepción tal que en ella la verdad o el bien no habrían de venirnos dados o impuestos desde fuera sino que, por así decirlo, tendrían que ser construidos por nosotros a través de un «consenso racional», de suerte que semejante concepción podría con toda propiedad ser llamada una concepción consensual de la verdad y el bien, es decir, una concepción en cuyo interior el logro de algún acuerdo sobre lo que entender por «verdadero» o por «bueno» sólo sería racionalmente factible por medio de un diálogo con nuestros semejantes (después de todo, y como ya lo sabía el pensamiento griego clásico, el «animal racional» aristoté- 
lico —el zóon lógon éjon o «animal dotado de razón»— no es en rigor otro que el homo loquens, donde esta última expresión constituiría una traducción latina de la fórmula griega tan legítima como la de homo rationalis y cabría traducirla a su vez a nuestro idioma como «el animal capaz de hablar» o, más exactamente, como el animal que — además de ser capaz de hablar- da la casualidad de que no tiene más remedio que hacerlo para poder desenvolverse en este mundo, entendiendo por tal tanto el mundo natural como el mundo social e incluido dentro de él, por descontado, el mundo moral).

Por consiguiente - y salvo mejor parecer de los teólogos — de la «muerte de Dios» de que se hablaba más arriba no se tendría por qué seguir el conocido adagio que sostiene que «Si Dios ha muerto (es decir, si no hay criterios absolutos de verdad ni de bien), todo habría de estarnos entonces permitido (tanto a título epistémico cuanto a título ético)». Una conclusión ésta que ni Apel ni Habermas aceptarían, a no dudarlo, de buen grado. Pero por más que ambos estén en su derecho de confiar en que toda «discusión racional» (esto es, todo auténtico diálogo llevado a cabo en nombre, y por medio, de la razón) presupone «una comunidad de interlocutores dispuestos a entenderse y llegar a un acuerdo» - es decir, a un consenso racional - lo cierto es que aún nos falta un paso más, y un paso decisivo, que nos aclare cuál pueda ser la «garantía» de que se vaya a producir un tal consenso.

Semejante garantía, para empezar, no nos la puede ofrecer esa forma convencional de «racionalidad» en que vendría a consistir la lógica deductiva. Como ha hecho ver Hans Albert, un autorizado discípulo y seguidor de Popper, cualquier intento de encontrar por vía deductiva una «fundamentación última» de un sistema de leyes científicas o de un sistema de normas morales nos conduce no ya a un dilema, sino a un trilema (el conocido como «trilema de Münchhausen» en honor del extravagante personaje que oficia como Barón de dicho nombre), trilema que parece forzarnos a elegir entre una u otra de tres alternativas a cual más insatisfactoria. Esto es, o bien optamos por deducir cada una de dichas leyes o dichas normas de leyes o normas previas que oficien como premisas, deduciendo a su vez tales premisas de otras premisas anteriores y así indefinidamente (lo que equivaldría a incurrir en una «regresión infinita», regressus infinitus en latín), o bien optamos por abandonarnos a una «circularidad» que indebidamente otorgue el rango de conclusiones a algunas de esas leyes o esas normas ya utilizadas como premisas con antelación (con lo que incurriríamos en lo que se llama en latín un circulus vitiosus), o bien optamos, finalmente, por una «ruptura del proceso deductivo» que caprichosamente haga pender todo el cuerpo de leyes o de normas a partir de premisas instituidas como tales de manera arbitraria (decisión ésta de interrumpir arbitrariamente la cadena deductiva que algún bromista ha bautizado con la macarrónica denominación latina de cogitus interruptus). Y de ahí que el racionalismo popperiano haya propuesto sustituir cualquier intento de «fundamentación última» de la ciencia o de la moral por 
un «examen crítico» comparativo destinado a poner a prueba en cualquier teoría o cualquier código su coherencia interna y su capacidad de resistir la competencia con otras teorías u otros códigos en litigio, que es lo que, en resumidas cuentas, mediría respectivamente en cada caso su racionalidad, sea teórica o sea práctica.

Pero si se le preguntara al racionalista popperiano, como lo han hecho Apel y Habermas, qué es lo que hay de «racional» en esa su preferencia por el racionalismo, ni Albert ni Popper sabrían con toda probabilidad qué responder y hasta es posible que consideraran absurda la pregunta, con lo que se expondrían al cargo - cargo que, ciertamente, no les ha sido ahorrado por sus adversarios- de que un racionalismo como el suyo no descansa sino en «un acto (pero un acto irracional) de fe en la razón».

Y quienes hagan suya esa objeción - como ya he dicho que es el caso de Apel y Habermas - es natural que busquen otra salida, salida que encerraría «el núcleo duro» de la teoría de la razón dialógica, demasiado duro quizás para el paladar de Habermas, quien ha acabado por renunciar al programa fundamentador apeliano y dejar solo a Apel en su empeño de encontrar la pretendida Letzbegründung o última fundamentación de la ciencia y la moral. Para ser exactos, tanto Apel como Habermas concordarían con los racionalistas popperianos en que, por más que sea posible axiomatizar deductivamente tales o cuales sistemas de leyes científicas o de normas morales, no parece en cambio posible una fundamentación deductiva de la ciencia o la ética en su conjunto (así como tampoco - de manera completa al menos, si es que hemos de hacer caso a Gödel y su teorema de incompletud - cabría la posibilidad de una fundamentación última de la lógica deductiva misma en su totalidad). Pero Apel — si no ya Habermas, repito - continúa pensando que, allí donde no cabe una fundamentación deductiva, cabría juzgar que resta todavía un intento de fundamentación trascendental de la ciencia y la moral, es decir, una fundamentación consistente en mostrar que algo que es condición de posibilidad de toda fundamentación no puede ya, ni necesita, ser a su vez fundamentado.

La garantía de semejante fundamentación no sería otra para Apel que lo que da en llamar «el a priori de la comunidad ideal de comunicación (ideale Kommunikationsgemeinschaft)» en que hace consistir el fundamento pragmático de todos nuestros usos lingüísticos - tanto científicos como morales-, concretándose en un principio que se dejaría compendiar por medio del imperativo de «argumentar en cualquier situación de tal manera que posibilitemos siempre un consenso en materias de interés común», principio o imperativo cuyo cumplimiento vendría a convalidar el recurso al lenguaje por parte de los miembros de la comunidad que así procedan, oficiando de esta manera a modo de «garante de la racionalidad (dialógica) de sus acuerdos».

Como fácilmente se deja apreciar, Apel no hace otra cosa en este punto que presentarnos una adaptación «lingüística» del llamado método trascendental de Kant, esto es, del método que Kant había empleado para fundamen- 
tar lo que llamaba «el factum de la ciencia» o «el factum de la moral» mediante la pregunta por sus respectivas «condiciones de posibilidad»o, dicho de otro modo, preguntándose «¿Cómo son posibles los juicios científicos»o «¿Cómo son posibles los juicios morales?». Kant respondería a estas preguntas bien sea por medio de la descripción de la estructura de nuestro aparato cognoscitivo (la dimensión espacio-temporal de nuestra sensibilidad y la servidumbre de nuestro entendimiento a principios como el principio de causalidad), bien sea por medio de la descripción de la estructura de nuestra conciencia moral (el ámbito en que la voz de la conciencia dejaría oír a un sujeto supuestamente libre y responsable los mandatos de la moralidad), «descripciones» ésas respectivamente llevadas a cabo por Kant en su Crítica de la razón pura o en su Crítica de la razón práctica y cuyas correspondientes «estructuras» (monológicamente descritas por Kant en esas Críticas) quedarían ahora «lingüísticamente transformadas» a través del registro de las deliberaciones (dialógicamente) mantenidas en el reino de la comunidad científica o en el reino de la comunidad moral en tanto que «comunidades (reales) de comunicación» a las que la «comunidad ideal» vendría a servir de referente o de modelo como «idea regulativa» de su funcionamiento. Una hazaña la de Apel, si así puede llamarse, que habría quedado registrada en su chefd'œuvre de 1973 Transformation der Philosophie («La transformación de la filosofía») y a la que podría servir de prudente contrapunto el breve pero sustancioso texto de Habermas Diskursethik. Notizen zu einem Begründungsprogramm («Ética del discurso. Anotaciones a un programa de fundamentación») recogido en la obra del autor Moralbewusstsein und kommunikatives Handeln («Conciencia moral y acción comunicativa») de 1983.

El programa fundamentador de Apel ha podido ser enaltecido como «un giro fascinante» operado en el interior del giro lingüístico de la filosofía contemporánea, pero presenta a mi entender un flanco débil relativo a la presunta obligatoriedad - que por lo visto habría de concernir sin excepción a todos los seres humanos - de secundar el principio o imperativo más arriba aludido, el cual podría ser ahora generalizado reformulándolo, según sugiere Apel, en los siguientes términos: «Contribuye» - nos dice- «mediante la argumentación a la realización de la razón en este mundo». Ahora bien, ¿qué sucedería si alguien cuestiona aquella obligatoriedad y se pregunta por qué habría de adherir a tal principio u obedecer a tal imperativo?

Dejando a un lado a Habermas, cuyo trascendentalismo sabemos más desfalleciente, Apel diría que su principio o imperativo resulta ser, en rigor, inesquivable, como vendría a probarlo el hecho de que quienquiera que se pregunte «por qué» habrá de prestarle su adhesión u obedecerlo se hallaría ya participando en la discusión argumentativa, es decir, estaría demandando razones (y cabría hacerle ver, en consecuencia, que ya ha hecho suyo el principio o imperativo cuestionado, de suerte que ni siquiera le sería dado argumentar en contra de la argumentación, cosa que sólo cabe hacer «argumen- 
tando», esto es, aceptando de antemano aquello que se pretende rechazar y por ende contradiciéndose). ¿Pero qué valor probatorio podría tener un argumento de esta índole? Cómo se le alcanza a cualquiera medianamente familiarizado con los entresijos de la historia de la teoría de la argumentación, se trata de una variante del llamado "argumento del et tu o el tu quoque», esto es, del «tú también», contemporáneamente rebautizado como el «argumento de la (auto)contradicción performativa», esto es, el argumento que se esgrime contra todo aquel cuyas acciones desmienten sus afirmaciones (como en el caso de un niño que afirmase que no puede pronunciar una palabra por medio de una frase en que de hecho la pronuncia, esto es, un niño que dijese «No puedo pronunciar abracadabra», a lo que cabría responderle que ya ha pronunciado «abracadabra»y, por tanto, se está autocontradiciendo). Un argumento éste de la autocontradicción performativa cuyo más remoto precedente se encuentra en la llamada consequentia mirabilis de la lógica medieval que aducía que «el intento de demostrar que la demostración es imposible demostraría, por el contrario, la posibilidad de la demostración», un argumento desde luego irrefutable para quien, en efecto, intente demostrar que la demostración es imposible, pero que sería en cambio absolutamente ineficaz frente a quien se niegue a entrar en el juego y renuncie a demostrar nada. Que es en definitiva lo que tendría que hacer, no menos consecuentemente, quien se hallase convencido de la «imposibilidad de la demostración», a saber, tendría que callarse, convirtiendo a ese su silencio en un fortín inexpugnable frente a la locuacidad de su interlocutor y dejando a este último, por así decirlo, «con un palmo de narices»... que es en filosofía el mejor remedio conocido contra la charlatanería.

Concluyente o inconcluyente (que sería ahora lo de menos, una vez dejada atrás la lógica deductiva en beneficio del enfoque pragmático-trascendental del lenguaje en lugar del sintáctico-semántico), el argumento de Apel no parece, en cualquier caso, suficiente para servir de pedestal a las ambiciosísimas pretensiones de su patrocinador cuando éste - invocando a Peirceprocede a sostener que una «comunidad ideal de diálogo» cuyos miembros tan sólo hiciesen uso de su razón, por lo demás la misma para todos, tendría que ser capaz de llegar — «siquiera sea a la larga» (in the long run) - a ponerse de acuerdo en torno a una «opinión final» (una ultimate opinion) común a todos ellos sobre lo que sea verdadero o bueno, lo cual equivaldría a suplantar — como ha señalado con acierto Hilary Putnam - «el punto de vista de Dios» (the God's viewpoint) o, por lo menos, comportaría volver a escribir con mayúscula no sólo la Razón sino, de paso, también la Verdad y el Bien (y quizás sea el momento de recordar, a título de conclusión del presente apartado, que no le habría venido mal a esta razón dialógica retener algo más de la humildad de sus orígenes socráticos: como el Sócrates de Platón mostrara ejemplarmente, el diálogo surge entre los seres humanos cuando la conciencia de su imperfecta racionalidad les impulsa a asociarse en ese esfuerzo coo- 
perativo de racionalidad en que el diálogo consiste, esfuerzo que resultaría prescindible, por superfluo, entre seres que fueran ya de entrada perfectamente racionales en lugar de hallarse sumidos, según acostumbra a ser lo más corriente, tanto en la confusión teórica cuanto en la irresolución práctica).

Comoquiera que sea, las debilidades argumentales de la teoría de la razón dialógica han dejado abierta entre otras una brecha al embate postmoderno, del que iba siendo hora ya de decir algo, aunque sea muy sumariamente, antes de despedir esta sesión, puesto que semejante acometida — la acometida del postmodernismo - no sólo se dirige al corazón de esa razón dialógica sino, como cabría haber esperado de su propia denominación, envuelve en rigor «una enmienda a la totalidad de la razón moderna» misma, sin excluir naturalmente a nuestro giro lingüístico.

Como creo haber dado a entender en su momento, la actitud frente al «postmodernismo» no se debería limitar a una reacción airada ante sus críticas, sino convendría en todo caso hacerla preceder de un intento de comprender a qué obedecen tales críticas, tras de lo cual (y sólo entonces) podría uno sentirse autorizado a declarar su desacuerdo radical con «el punto de vista postmoderno» o, cuando menos, con la manera habitual como dicho punto de vista aparece expuesto y es defendido por algunos de sus partidarios. Y, como siempre que tengo que echar mano de alguien que represente dicho punto de vista postmoderno, elegiré para sorpresa quizás de algunos a un pensador que se halla en rigor lejos de considerase a sí mismo un "postmoderno», autocalificándose más bien como un representante del punto de vista pragmatista (una corriente filosófica esta última —el «pragmatismo»— a la que procede considerar todo lo clásica que le sea dado serlo a una corriente filosófica en Usamérica, para servirme de la expresión oportunamente acuñada por Carlos Thiebaut). Aunque, si bien se mira, tampoco deja de ser cierto que en el pensador elegido vienen a darse cita todas las influencias, desde Foucault a Derrida pasando por Lyotard y algunos cuantos nombres más (todos ellos emparentados con los diversos «estructuralismos» y «postestructuralismos» de rigor), que en mayor y mejor medida han contribuido a configurar filosóficamente la postmodernidad.

Como se habrá ya adivinado, me estoy refiriendo a Richard Rorty, con cuya mención vendría a cerrarse el bucle de los avatares de la razón comprendidos dentro de ese avatar de la razón que fue el giro lingüístico. Y con ello retornaríamos al inicio de nuestro recuento con la filosofía analítica en tanto que primera protagonista de dicho giro, pues Rorty no sólo fue en sus inicios un filósofo analítico más o menos sui generis sino - como también sabemos- el primer divulgador, ya que no el acuñador, de la expresión «giro lingüístico» que da título a su tan traída y llevada antología de los años sesenta del pasado siglo The Linguistic Turn (subtitulada Recent Essays on Philosophical Method y precedida de una larga Introducción suya, no exenta ya por entonces de autocrítica, cuyo encabezamiento a su vez rezaba Metaphiloso- 
phical Difficulties of Linguistic Philosophy). Nada de lo cual le ha impedido oficiar luego, según dijimos al comienzo, como cancelador del propio giro lingüístico desde las coordenadas postmodernas que trataremos de examinar a continuación.

Para empezar por la «razón» misma cuyos avatares nos han venido interesando, Rorty no sólo no la escribe con mayúscula sino que procura evitar su simple mención salvo a título derrisorio (esto es, con el fin de burlarse de ella o ridiculizarla, como cuando se sirve del vocablo para escarnecer lo que sarcásticamente llama «el tribunal de la razón») y otro tanto sucede con el «racionalismo» - lo que expresamente llama «el racionalismo moderno»— desde Descartes a Kant (mezclados así, al desgaire, en un totum revolutum), racionalismo al que reprocha su «autoritarismo», acusándole de imponer un asfixiante corsé de hierro tanto a la epistemología como a la ética (el mejor compendio hoy por hoy de su posición al respecto puede encontrarse en el texto El pragmatismo, una versión. Anti-autoritarismo en epistemología y ética, un texto éste que - aun si precedido de versiones parcialmente similares en inglés - ha sido originariamente publicado en español el año 2000 como «Lecciones impartidas en la Cátedra Ferrater Mora de la Universidad de Girona», versión a la que me complace citar y referirme en homenaje a la ya recordada labor divulgatoria del «giro lingüístico» llevada a cabo por Ferrater en nuestra lengua).

Por lo demás, Rorty también propone hacer desaparecer del vocabulario filosófico, junto con la «razón» y el «racionalismo», términos tales como «verdad» (y su correlativo «objetividad») o «bien» (y su correlativo «justicia») a los cuales propone sustituir por «el libre consenso» de la comunidad de los usuarios de un lenguaje — no «el» lenguaje, sino «un» lenguaje particular - en lo que atañe a las «creencias» de dichos usuarios (creencias indiscernibles a todos los efectos de sus simples «prejuicios») o en lo que atañe a sus «convicciones» (convicciones de nuevo indiscernibles a todos los efectos de sus simples «deseos»). Un consenso el de Rorty que nada tendría que ver, por descontado, con el «consenso (pretendidamente) racional de la teoría de la razón dialógica», el cual podría tratar de extenderse - siquiera sea «idealmente»— a «toda la humanidad» en su conjunto, entendiendo por tal la especie humana sin acepciones de lugar ni de fecha, es decir, trascendiendo cualquier contextualización espacial (por ejemplo, esta o la otra «cultura») o cualquier contextualización temporal (por ejemplo, esta o aquella «época»), todo lo cual vendría a desembocar - según denuncia Rorty con parcial (sólo parcial) acierto- en la universalidad puramente abstracta de una ciencia y una moral enteramente descontextualizadas, esto es, enteramente desprovistas de raíces sociohistóricas, ciencia y moral que habrían de suponerse protagonizadas, en opinión de Rorty (de nuevo parcialmente, y sólo parcialmente, acertada), por arcángeles en vez de por seres humanos de carne y hueso. Los «consensos rortyanos», por el contrario, presumirán siempre de ser «huma- 
nos, demasiado humanos» a lo Nietzsche y se hallarán indefectiblemente confinados a un «aquí» y a un «ahora» que - por más que pudieran ensancharse, de modo variable, en el espacio y en el tiempo (como cuando, pongamos por ejemplo, una cultura absorbe a otras o una época es heredada por las que le suceden), esto es, por más que dicho «aquí» y dicho «ahora» pudieran autotrascenderse - nunca nos autorizarían a pasar por alto, concluye Rorty, las severas constricciones impuestas a la vigencia de los consensos en cuestión por sus contextos y demás circunstancias condicionantes de la misma.

La posición de Rorty, como vemos, derrocha iconoclastia; algo que en filosofía puede sin duda resultar estimulante y se halla a la base de la deuda que, en este sentido, tiene contraída con él el pensamiento contemporáneo. Pero, administrada a grandes dosis, la iconoclastia puede también contribuir a obnubilar la percepción de los matices, de los que la filosofía tampoco puede prescindir; y las conclusiones que Rorty extrae de cuanto llevamos visto plantean problemas, como los tres problemas que se enumeran a renglón seguido, cuyo tratamiento a manos de nuestro autor deja bastante que desear en lo tocante a la atención prestada a esos matices. Así ocurre, en primer lugar, con la exacerbación rortyana del contextualismo de nuestras creencias y nuestras convicciones; en segundo lugar, con su minusvaloración del sentido que quepa atribuir a empresas tales como la búsqueda de la verdad o la objetividad y el esfuerzo en pro del bien o la justicia; y, en tercer lugar, con la insuficiencia del margen de aspiración a la universalidad que rortyanamente se le concede a la propia racionalidad tanto teórica como práctica, problemas todos ellos que en lo que sigue me limito a apuntar someramente.

Primer punto. Por lo que se refiere al «contextualismo», el pragmatismo de Rorty ha heredado de la concepción pragmática del lenguaje por parte del segundo Wittgenstein (esto es, de la concepción de los juegos de lenguaje como formas de vida que antes veíamos) una visión de los contextos - entendiendo por tales, supongamos, las comunidades de quienes comparten conjuntos de creencias y/o de convicciones - como si se tratara de compartimentos estancos y mutuamente incomunicables, si es que no inconmensurables, entre los que nada en común habría que nos permita juzgarlos comparativamente. En cuyo caso, tan respetables vendrían a ser en cuanto a sus creencias los miembros de una comunidad de quiromantes que los de una comunidad de médicos interesados en la prospección de la evolución de una enfermedad, con la única diferencia de que los médicos basarían su prospección en el examen clínico de los pacientes en tanto que los quiromantes se darían por satisfechos con leerles las rayas de la mano; y, de análoga manera, tan dignas de ser tenidas en cuenta serían las convicciones que animan a los miembros de una comunidad de cooperantes en países subdesarrollados como los que en su día animaron a Hitler y su pandilla en orden a consumar el Holocausto. El segundo Wittgenstein, como sabemos, dio en ocasiones la sensación de bordear 
ese relativismo, pero también la cuestión del relativismo parece traerle a Rorty sin cuidado, puesto que lo que le preocupa no es si algún día seremos recompensados con la «medalla de la verdad» o la «medalla del bien» sino que «cada vez haya más gente que se una a nuestra comunidad», lo que -a falta de mayores, o mejores, explicitaciones - parece remitir sencillamente al canon usamericano, nordatlántico o comoquiera que demos en denominarlo, respecto del cual «ordenar» (más bien que «comparar», «preferir» o «elegir») la pluralidad de los contextos epistémica y éticamente diversificados que se dan a lo largo y lo ancho de este mundo, donde la «ordenación» se entiende aquí como sinónimo de «jerarquización»... siquiera sea de facto, ya que tampoco parece posible justificar de iure lo que en definitiva da la sensación de reducirse a una opción por el etnocentrismo.

Segundo punto. Tras cuanto acaba de decirse, nada de extraño tiene que Rorty considere irrelevantes, cuando no contraproducentes, procesos tales como «la búsqueda de la verdad o la objetividad» y «el esfuerzo en pro del bien o la justicia». Desde luego, no deja de ser cierto que actitudes como la presunción de haber encontrado la verdad y poseerla (lo que se entiende de ordinario por «creerse en posesión de la verdad») o la presunción de haber alcanzado el bien sin mezcla de mal alguno (lo que de ordinario se cree que presupone «ser capaz de distinguir con nitidez entre el eje del bien y el eje del mal») alimentan el peor de los dogmatismos y han podido obligarnos a reconocer que «la verdad no siempre nos hace libres» o que «no hay peor tiranía que la del bien». Pero el temor a pecar de dogmáticos no debiera arrojarnos de bruces al escepticismo, obligándonos a renunciar a la búsqueda de la verdad (o la objetividad) y al esfuerzo en pro del bien (o la justicia), que son ambos procesos valiosos independientemente de que lleguen o no lleguen a la plenitud de su culminación. No hay que olvidar el famoso dictum del ilustrado Lessing que - una vez adaptado para nuestros propósitos - vendría a proclamar: «Si Dios tuviese en su mano izquierda la tendencia a la verdad y al bien, y en su mano derecha la verdad y el bien mismos, yo le diría: Señor, dame la tendencia a la verdad y al bien, puesto que la verdad y el bien mismos sólo están hechos para Ti». Y ni siquiera está excluido que en el camino (que sería siempre preferible a la posada, como le hace decir Cervantes a don Quijote) tropecemos, ya que no con «la» verdad en sí o «el» bien en sí, sí por lo menos con verdades parciales y con concretos bienes, como vendrían a serlo esos modestos hallazgos de la razón teórica que son para la ciencia - en los ejemplos de Jesús Zamora Bonilla - la tabla periódica de los elementos o la constitución celular de los seres vivos (hallazgos que nos parecen hoy tan firmes que no ha lugar ya a considerarlos «construcciones sociales» como lo serían para algunos filósofos postmodernos de la ciencia) y otro tanto vendría a ocurrir con esas elementales conquistas de la razón práctica representadas por los derechos humanos, esto es, derechos tales como el derecho a la vida, la educación, la salud y el trabajo, así como a la lengua y la cultura propias 
(derechos cuya importancia no empece tampoco a su elementalidad, puesto que no hay necesidad de ennoblecerlos - como haría el iusfilósofo premoderno - con su dudosa caracterización como «derechos naturales» cuando en rigor se trata, esta vez sí, de otros tantos logros de las «luchas sociales» de la gente por conseguir su instauración). Y ni siquiera es menester invocar aquí a la razón, teórica ni práctica, para justificar aquellos hallazgos o aquellas conquistas, cuando a tales efectos bastará con esforzarnos por «dar razón» (lógon didónai) de unos y de otras, de acuerdo con la tradición de nuestros clásicos que discurre de Sócrates a Aristóteles pasando por Platón; o, mejor aún, «dar razones» en favor de aquellas nuestras creencias y nuestras convicciones, pues también aquí «la razón» cedería el paso a las parciales y concretas, modestas y elementales razones de que habla Wilfrid Sellars y, en su estela, Robert Brandom cuando propone sustituir a la razón por «la articulación de las razones», articulación que parece preferible a la ordenación jerarquizante de los contextos o las comunidades rortyanas que antes veíamos, con la ventaja adicional de que tales razones son la llave de acceso al universo de las teorías y las prácticas argumentativas en las que se materializa el razonar humano cuando se trata de argumentar o «si de argumentar se trata», para decirlo con el título de una obra del filósofo de la lógica Luis Vega.

Tercer (y último) punto. Se trata en este caso de un «tercer reproche» que, antes de dirigírselo a Rorty (o además de ello), tendría también que dirigírmelo a mí mismo y convertirlo en un autorreproche. Y es el de que para hablar del transcurso de la razón moderna a la postmoderna, si nos fijamos bien, no hemos necesitado desviarnos por un instante del cauce de lo que se conoce como «la razón occidental», como si ésta fuera la única existente en nuestro mundo: Rorty, que criticaba el supuesto «universalismo de la razón» por considerarlo una muestra de universalidad abstracta, tal vez pueda sentirse confortablemente instalado en su reserva etnocéntrica del (north)american way of life, pero - para decirlo con las palabras de nuestro colega peruano Miguel Giusti, inspiradas en una conocida metáfora de Octavio Paz- lo cierto es que la razón, que sin duda precisa de raíces que la anclen sociohistóricamente, necesita asimismo de alas que le permitan sobrevolar nuestra civilización occidental y, sin merma de nuestro anclaje en ella, abrirse a una visión del mundo de carácter «multicultural» o multicivilizatoria enriquecida a través de la interpenetración con otras civilizaciones. Y la urgencia de recorrer semejante vía al cosmopolitismo resulta hoy tanto más inexcusable cuanto que la alternativa al proyecto cosmopolita parece reducirse en estos tiempos a la resignación a un catastrófico «choque de civilizaciones» etnocéntricamente concebido, para colmo, como un choque entre «la civilización» (que habría de ser siempre la nuestra) y «la barbarie» (que sería siempre la de los demás), que es lo que entre nosotros no se cansan de denunciar colegas tan caracterizados como Reyes Mate, Francisco Fernández Buey o Pablo Ródenas. 
Sin tiempo ya para otra cosa que aludir a él y darle un nombre, quizás se imponga recurrir aquí a un nuevo y por el momento innominado avatar de la razón que se viene imprecisamente configurando, desde diversas procedencias y con matices asimismo diversos, en el curso de los últimos años de nuestro medio siglo. Se trata en sustancia de la lenta, pero presumiblemente imparable, consolidación en determinados ámbitos filosóficos del recurso a la noción de «razonabilidad» (reasonableness) en cuanto diferente de la de «racionalidad» (rationality). Stephen Toulmin se ha servido de ella en los dominios de la filosofía y la historia de la ciencia, así como John Rawls ha hecho otro tanto en los dominios de la filosofía moral y política, con la intención en ambos casos — por lo demás, distintos y no necesariamente conexos entre sí- de patentar un «uso de la razón» ya sea más laxo o ya sea más amplio que el de la racionalidad ordinaria (en cuanto a mí, me gustaría poder servirme de esa noción para conceptuar no sólo un distinto uso de la razón - distinto, quiero decir, de sus usos estrictamente «teórico» y estrictamente «práctico»—, sino también una idea de universalismo menos abstracta que la acostumbrada y basada, frente a ella, en la «reciprocidad entre las partes», que me parece que es el tipo de «universalidad» que mejor se acomodaría a las exigencias del «cosmopolitismo» a que antes aludíamos). A diferencia de los usos teórico y práctico de la razón respectivamente inspirados en las dos primeras Críticas de Kant, la razonabilidad así entendida (Vernünftigkeit en alemán, más bien que Rationalität) remitiría a su tercera Crítica, a saber, la del juicio, la facultad de juzgar o el discernimiento, según recientemente ha traducido entre nosotros Roberto Rodríguez Aramayo la Urteilskraft como «capacidad de discernir». Y mi propia interpretación de la razonabilidad vendría a inspirarse en un pasaje de dicha última obra sobre el que a otros efectos ha llamado la atención Hannah Arendt, pasaje en el que Kant sienta la máxima que nos invita a «pensar en el lugar de cada otro» (an der Stelle jedes anderen denken).

Aun cuando dicha máxima descansa para Kant en una suerte de sensus communis de la especie humana, lo cierto es que el precepto envuelto en ella parece bastante más fácil de enunciar que de poner en práctica, puesto que inevitablemente tropieza con lo que alguna vez he llamado la incomodidad del lugar del otro, un lugar a decir verdad bastante más incómodo de lo que hubiera sospechado Leibniz cuando lo bautizó como la place d'autrui. En efecto, el precepto kantiano de pensar en el lugar de cada otro - si es que pretende ir más allá de la retórica invitación a proyectarnos imaginativamente en los demás mediante la adopción eventual de sus puntos de vista - tendría de hecho que implicar, en un sentido real y no meramente virtual, la resolución de intercambiar «lugares» con ese otro y, por lo pronto, de «ponernos» literalmente «en su lugar». Pero esta operación resulta un tanto ardua de ejecutar, toda vez que ponerse en el lugar del otro podría significa para ese otro una indeseable «ocupación de su lugar», esto es, una invasión o usurpación del 
mismo. Y no estoy hablando de figuraciones, como se le alcanza a cualquiera que contemple la actual exportación manu militari de los valores de nuestra civilización occidental al Próximo y Medio Oriente valiéndose de la guerra de Irak, tal y como antes se trató de hacer en el Lejano Oriente mediante la guerra del Vietnam. Mientras que, vistas las cosas desde el lado opuesto, la reciprocidad con el otro nunca será completa si no comporta el mismo tiempo la firme voluntad de dejar a ese otro «ocupar nuestro lugar» — es decir, de poner a ese otro en nuestro lugar - permitiéndole por ejemplo compartir con nosotros las bases materiales que le aseguren la plena participación en la universal sociedad del conocimiento así como el disfrute en plenitud de los no menos universales derechos de la humanidad, algo que no sé bien si quienes gozamos de todo ello dentro del Primer Mundo estaríamos dispuestos a hacer, sin reservas ni restricciones, con nuestros semejantes del Segundo, Tercer y Cuarto Mundos.

En tanto no lo hagamos, «el lugar del otro» seguirá siendo un lugar incómodo y de nosotros dependerá que se convierta en razonablemente confortable o en un inhóspito infierno, que es la diferencia que existe entre un Encuentro, no digamos una Alianza, de Civilizaciones y un Choque, o un Conflicto, e incluso una Guerra Mundial entre esas Civilizaciones...

\section{Postmodernidad y "pensamiento postmetafísico»}

¿Y qué hay, a todo esto, de nuestro prometido balance y perspectiva del giro lingüístico por donde comenzábamos? A la luz de cuanto llevamos visto, y si nos tomamos todo lo en serio que merece la equiparación de «lenguaje»y «razón» auspiciada por el doble sentido - tantas veces sacado a colacióndel vocablo lógos, el medio siglo de hegemonía del giro lingüístico que estamos dejando atrás habría venido a rendir culto, proponiéndoselo o no, a una concepción de la filosofía como meditatio rationis o «reflexión en torno a la razón». Lo que sin duda ayuda a explicarnos la vehemente descalificación del giro lingüístico por parte de ese virtuoso de la boutade que fue el Richard Rorty postmoderno cuando, sin más ni más, dio en tacharlo de una tempestad en la tetera académica.

Por lo que a mí respecta me hallo convencido, dejando a un lado las boutades, de que de semejante giro sólo cabe salir por medio de eso que Hegel habría llamado una Aufhebung, esto es, aquella operación intelectual que - al mismo tiempo que la «superación» de algo (en nuestro caso, la superación del giro lingüístico) - comportase de algún modo su «conservación» (en nuestro caso, la conservación de sus conquistas, conquistas que ciertamente no han sido pocas en cuanto al incremento del rigor y la precisión filosóficas, incluida su contribución a la claridad mental de los propios filósofos).

De modo que la única reserva que tendría por mi parte que oponer a la vigencia actual de semejante giro es totalmente ajena a las de Rorty y se li- 
mita a llamar la atención sobre lo que tantas veces se ha dicho de los «giros» o, para el caso, las «revoluciones». Como advertía al respecto Albert Camus, hay que tener mucho cuidado con las revoluciones - las revoluciones políticas, por ejemplo, no menos que las astronómicas, de las que las políticas toman a título metafórico su denominación - porque mientras un giro de 180 grados podría venir a comportar un cambio significativo dentro de una determinada situación, una pasada de rosca que convirtiera a dicho giro en un giro de 360 grados (que es lo que, etimológicamente hablando, quiere decir una «revolución») se arriesgaría a dejar las cosas tal como estaban. Y por eso Camus, como es sabido, desconfiaba avisadamente de que en la historia hubiera habido, o pudiera haber, una auténtica revolución que viniese a ser «la definitiva», prefiriendo en lugar de ello describir a dicha historia como «la suma, presumiblemente inacabable, de nuestras rebeliones sucesivas».

Pero, a la vista de semejante observación, se torna verdaderamente irresistible la tentación de invocar por nuestra parte el celebérrimo apotegma wittgensteiniano según el cual «la filosofía lo deja todo tal como está» (Sie lässt alles wie es ist, como se lee en el parágrafo 124 de las Investigaciones filosóficas). Un apotegma éste que - cualquiera que haya podido ser, cosa que no hace al caso averiguarlo ahora, la intención originaria de Wittgenstein al pronunciarse en esos términos - no ha faltado quien tratara de interpretarlo en clave irónica (e incluso en clave melancólica), como tampoco ha faltado quien lo interpretase en su aplastante literalidad (cuando no en clave cínica), es decir, como el palmario reconocimiento de la inanidad de toda filosofía. Y puestos a buscarle interpretaciones a la dichosa frase, también cabría insinuar que la afirmación de que «la filosofía lo deja todo tal como está» abre la puerta a la pregunta acerca de qué podría ese «todo» querer decir sino sencillamente «todo lo real», esto es, la realidad en su totalidad a la que la filosofía, cada filosofía, añade cuando menos ese incremento de la realidad constituido por su propia «interpretación de la realidad». De suerte que, cuando se afirma que la filosofía lo deja todo (o sea, todo lo real) tal como está, ¿no cabría también insinuar que semejante afirmación implica por lo pronto una alusión omniabarcante a la totalidad de la realidad, que es lo que desde siempre ha caracterizado a ese tan problemático como insoslayable capítulo de la filosofía que a través de los siglos se ha venido llamando metafísica? Y antes de tirar nadie contra ella la primera piedra desde los aledaños de llamado "giro lingüístico», convendría recordar que el auténtico inventor y acuñador de dicha expresión - que fue, según Rorty lo reconocería expresamente y nosotros sabemos ya, el neopositivista Gustav Bergmann - la albergó entre las páginas de un libro suyo nada menos que titulado «La metafísica del positivismo lógico» (The Metaphysics of Logical Positivism, 1954), como dando a entender que también a ese movimiento antonomásticamente antimetafísico representado por el Círculo de Viena le subyacía una metafísica. 
No hay que añadir, empero, que «la realidad» —al igual que «la verdad», «el bien» o «la razón»- constituye una expresión proscrita para el pensamiento postmoderno, el cual, como señaladamente acontece en el caso de Rorty, alardea de ser al mismo tiempo un pensamiento postmetafísico (una veleidad esta última en la que, no sin algún oportunismo, ha llegado a incurrir incluso un crítico tan acerbo del postmodernismo como Habermas cuando abiertamente interpreta su propio «pensamiento postmetafísico», su nachmetaphysisches Denken, a la manera de un corolario del giro lingüístico).

Pero, olvidándonos de este último Habermas y de su inmoderado afán de figurar en todas las procesiones sin por eso dejar de repicar en ninguna de ellas, convendría recordar en este punto la advertencia del historiador de la metafísica Miguel Candel cuando - a propósito de la mentada fusión de «pensamiento postmoderno» y «pensamiento postmetafísico»- conjetura que de semejante fusión sólo puede salir el postpensamiento, es decir, la renuncia sin más al pensamiento filosófico.

Por descontado, nadie que sea o se considere hijo de la Ilustración - $\mathrm{y}$ que no haya renegado de ella a lo Alasdair MacIntyre - tendría hoy el menor interés en resucitar la vieja y desacreditada metafísica premoderna o preilustrada (MacIntyre sí, como es sabido, y sin hacerle ascos ni al tomismo). Pero la propia Modernidad se resistió a darle la espalda a la metafísica y, como en nuestros días nos lo recuerda John McDowell, nada menos que Kant —el Alleszermalmer o enterrador de la metafísica premoderna - subdividió su entera obra en esos dos grandes apartados que respectivamente respondían a los epígrafes de «metafísica de la naturaleza» (la Metaphysik der Natur) y «metafísica de las costumbres» (la Metaphysik der Sitten). Y nosotros, modestamente, no vamos a ser menos a la hora de hacerle un sitio a la metafísica y, de manera señalada, a la metafísica (de la) moral (aun si no es menester - sirva la aclaración de excusa no pedida - que para ello hagamos nuestro el acento neoclásico que McDowell acostumbra a poner en el empeño).

\section{El horizonte metafísico de la ética \\ 4. ¿Qué entender por «metafisica»?}

En su Ética de 1958, Aranguren hablaba de «la subordinación de la ética a la metafísica», entendiendo por esta última la metafísica moral a lo Zubiri, esto es, la teoría de la realidad buena. En su opinión, la metafísica zubiriana así entendida era «la menos metafísica de las metafísicas conocidas», lo que no ahorró a Aranguren someterla a una particular «crisis de la metafísica» en la que, por así decirlo, recapituló ontogenéticamente la filogénesis de la crisis de la metafísica moderna y pasó a cuestionar la proclamada subordinación de la ética a cualquier género de metafísica, acentuando en cambio 
su vinculación con las ciencias humanas y sociales de la moral como la antropología y la sociología morales (de semejante nuevo enfoque de la ética da testimonio, además de su Ética y política de 1963, el texto Lo que sabemos de moral de 1967, reeditado en 1983 bajo el título de Propuestas morales). Pero Aranguren nunca dejó de interesarse por la metafísica, a la que en su libro La comunicación humana, también de 1967, pasaría significativamente a concebir como «un sistema de preguntas», más bien que de respuestas, relativas al sentido último de la realidad sin excluir dentro de ésta nuestras propias vidas.

Comoquiera que sea, no es menester pensar que todas las «preguntas metafísicas» constituyan preguntas «últimas» que - a la manera de la interrogación por el sentido de la vida - haya que caracterizar wittgensteinianamente como «abiertas» si es que no acaso como «incontestables», esto es, como «preguntas sin respuesta».

Por el contrario, el antes aludido John McDowell concedería sin darle demasiadas vueltas que de buen número de cuestiones metafísicas (por llamar de este modo a las preguntas metafísicas más o menos «susceptibles de ser respondidas») puede muy bien hacerse cargo una metafísica sobriamente «naturalista», ya sea concebida como una reflexión sobre el «mundo natural» y nuestra instalación dentro del mismo, ya sea concebida como una reflexión sobre nuestra instalación en un «mundo moral» creado por nosotros pero a su vez interpretable, al estilo tradicional, como una «segunda naturaleza» (lo que, según habremos de ver más adelante, plantea el arduo problema de los $l i$ mites del naturalismo dentro del pensamiento ético).

Puestos, no obstante, a darle un nombre a esta primaria aproximación a la metafísica - que trataría sencillamente de encarar lo que daremos en llamar la pregunta por «lo real»—, preferiría echar mano por mi parte de la denominación más castiza de «metafísica de cercanías» debida a Miguel Candel, asimismo ya mencionado con anterioridad. En su reciente libro de ese título, Metafísica de cercanías, Candel advierte contra la «presbicia mental» de quienes dan la sensación de creer que «el ojo metafísico» sólo está hecho para «mirar a lo lejos»: «(En la metafísica de cercanías) el ojo metafísico mira a lo que tiene más cerca... Y como el espectáculo de este mundo se ha vuelto tan deslumbrante, tan erizado de fogonazos que ciegan los ojos sin iluminar las cosas, por eso hay tanto présbite del espíritu... incapaz de ver lo que pasa a una distancia igual o menor que la de sus narices». Para acostumbrarse a viajar metafísicamente no conviene empezar, en consecuencia, por «trayectos de largo recorrido», sino por frecuentar más bien las estaciones y los trenes de cercanías - con sus correspondientes destinos ferroviarios de corto alcance - cuya incomodidad, escasa velocidad e incesante traqueteo contribuyen a la vigilia del viajero y, aun permitiéndole a intervalos dormitar una breve cabezada que no viole la drástica consigna de Marc Strand ya conocida de nosotros, mantienen embridada a la ensoñación. 
Los «sueños», comenzando por los de la razón, pueden producir monstruos como sobradamente ya sabemos. Pero también hay «sueños racionales y/o razonables» de los que la razón humana no puede prescindir, como los que se relacionan con el ansia de saber o con el ansia de vivir felizmente, sueños éstos que tienen más que ver con la dimensión de la «posibilidad» que con la dimensión de la «realidad» y nos obligan a introducir una nueva pregunta - la pregunta por «lo posible»- entre la pregunta por «lo real» y la pregunta «sin respuesta». Y con el escalonamiento de nuestras tres preguntas, a las que sucesivamente habremos de pasar revista, daremos por someramente esbozado lo que me gustaría llamar en adelante «el horizonte metafísico de la ética», a lo largo del cual discurriremos desde la metafísica de cercanías a la de lejanías pasando por la de la distancia media.

\section{Tres capitulos de la metafísica (de la) moral}

Pero, antes de entrar en los detalles de semejante esbozo, quizás convenga decir algo de carácter aún más general acerca de la legitimidad o ilegitimidad de la empresa metafísica en sí misma, pues el que en nuestros días se ha dado en bautizar como «pensamiento postmetafísico» no ha sido desde luego el único, ni tampoco el primero, en cuestionar dicha legitimidad dentro del marco de la filosofía del siglo XX y lo que va del XXI. Con la excepción ya señalada de Gustav Bergmann y algún que otro esporádico correligionario suyo, el «positivismo lógico» o neopositivismo del Círculo de Viena se adelantó en decenas de años a cualquier otro movimiento filosófico contemporáneo en aquella tarea de deslegitimación de la metafísica. Una deslegitimación que acabaría alcanzando resonancia universal al verse compendiada por el autor británico Alfred J. Ayer en su bestseller filosófico Language, Truth and Logic («Lenguaje, verdad y lógica», 1936), donde tuvo ocasión de popularizar la consabida clasificación tricotómica de los enunciados lingüísticos de que sin más preámbulos pasamos a ocuparnos.

De acuerdo con ella, los enunciados lingüísticos podrían ser o bien enunciados analíticos, esto es, «verdaderos por definición», como «Todos los triángulos son triláteros» (en el que triangularidad y trilateralidad serían nociones que se coimplican mutuamente); o bien enunciados empíricos, esto es, «verificables por recurso a la experiencia», como "Todos los metales son conductores de la electricidad» (el cual podría ser comprobado empíricamente en cada caso sometiendo a una pieza del metal de referencia al paso de una corriente eléctrica); o bien, por último, enunciados metafisicos que «ni son verdaderos por definición ni tampoco son empíricamente verificables, por lo que habría que declararlos desprovistos de significación o carentes de sentido», como sucede con el enunciado «Todos los seres humanos poseen, además de su cuerpo, alma inmortal» (donde la inmortalidad no se sigue analíticamente por implicación de la idea de humanidad ni hay tampoco manera de 
comprobarla empíricamente, a diferencia de lo que sucede con la mortalidad del cuerpo).

No hay que decir que los metafísicos reaccionaron con escandalizada indignación ante este tipo de aseveraciones, pero la indignación - por mucho escándalo que la suscite - se halla lejos de constituir ningún argumento, de suerte que la confrontación se habría zanjado con la indiscutible victoria dialéctica de Ayer de no haber sido por la serena intervención en el debate de un metafísico compatriota de este último, a saber, su colega el también filósofo Robin G. Collingwood.

En sus diversos escritos sobre metafísica, y de manera muy especial en su An Essay on Metaphysics («Ensayo sobre la idea de la metafísica», 1940), Collingwood asumiría sin pestañear la tricotomía de Ayer entre afirmaciones «analíticas», «empíricas» y «metafísicas», pero cuidando de advertir que - mientras los dos primeros tipos de afirmaciones (en nuestros ejemplos, «Todos los triángulos son triláteros» $\mathrm{o}$ «Todos los metales son conductores de la electricidad») resultaban susceptibles según vimos de ser tenidos por verdaderos o por falsos, es decir, se trataba en ambos casos de auténticos enunciados o proposiciones - las afirmaciones metafísicas (a las que cabría llamar ahora, para distinguirlas de las anteriores, juicios metafísicos) no constituyen en rigor enunciados ni proposiciones, ni hace al caso, por tanto, preguntarnos por su verdad ni por su falsedad. Para poner un otro ejemplo que el de la inmortalidad del alma, pensemos en una afirmación o un juicio de esa índole como el de que «Todo acontecimiento tiene una causa», que no es tampoco ni «analíticamente» verdadero (las nociones de acontecimiento y causalidad no se coimplican necesariamente) ni «empíricamente» verdadero (a diferencia de la clase de los metales, cuyos miembros eran finitos en número, la infinitud del número de acontecimientos imaginables nos impediría ir comprobando uno por uno si han tenido o no una causa). Pese a lo cual la afirmación de que «Todo acontecimiento tiene una causa» no es una afirmación absurda o un sinsentido, sino se trata de un juicio sobre el que descansa nada menos que el edificio entero de la mecánica newtoniana, que no se habría podido tener en pie de no contar con semejante base de sustentación. Para decirlo con Collingwood, la afirmación de que «Todo acontecimiento tiene una causa» no es exactamente un enunciado o una proposición, $n i$ analítica $n i$ empírica, sino «una presuposición absoluta» (an absolute presupposition) de la física de Newton... que, en cuanto tal, no pertenece al cuerpo de esta última sino al de la metafísica, caracterizada por Collingwood precisamente como «la ciencia de las presuposiciones absolutas». En sí misma considerada, la metafísica sería «una disciplina histórica»: lo que para la mecánica newtoniana era una presuposición absoluta no necesita serlo en cambio para la mecánica cuántica, por más que Einstein se inclinara, como es sabido, por mantenerla tanto en los dominios de la microfísica cuanto en los de la macrofísica. Y mientras que la presuposición de la causalidad sería lo que en términos kantianos vendríamos a llamar «una presuposición de la razón teó- 
rica», la inmortalidad de la que antes hablábamos podría ser asimismo para Kant «una presuposición (o un postulado, para decirlo con sus términos) de la razón práctica», aun cuando - en la medida en la que la inmortalidad presupone a su vez alguna suerte de fe religiosa, como la creencia en que la práctica de la virtud ha de verse recompensada en otra vida, ya que no desde luego en ésta, con la dicha de la eterna felicidad-, la inmortalidad no sería para Kant una presuposición tan absoluta como lo es la de la libertad en cuanto ratio essendi de la moralidad, es decir, una presuposición tal que sin ella no cabría tan siquiera presumir que exista la ética. Dicho en otros términos, mientras que la causalidad sería para Kant, no menos que para Newton, la clave de bóveda de su metafisica de la naturaleza, la libertad vendría a ser por su parte la clave de bóveda de su metafisica (de la) moral, así como - descendiendo ahora a sus cimientos- el presupuesto básico de la existencia misma de la ética.

Pero antes de proseguir, y si se me permite un breve inciso, me gustaría poder reclamar atención sobre el curioso «aire de familia» (una Familienähnlichkeit, para decirlo una vez más wittgensteinianamente) que da la sensación de concurrir entre lo que consideraba Collingwood «presuposiciones» y lo que entre nosotros gustaba Ortega de llamar «creencias», contraponiéndolas a las «ideas»: mientras que las ideas «se tienen», las creencias más bien nos tienen o nos «sostienen» a nosotros, pues en ellas «se está», por así decirlo, históricamente hablando; y, tanto para Ortega como para Collingwood, creencias y presuposiciones constituirían afirmaciones (o juicios) metafísicas(os), si bien vendrían a serlo de una metafísica que - en tanto que disciplina histórica - bien podría llamarse «metahistoria» (tanto o más metá ta historiká que metá ta physiká).

$\mathrm{Y}$, tras estos obligados prolegómenos, procederemos a encarar nuestros tres tipos de preguntas metafisicas siguiendo un orden de menor a mayor complejidad, correlativo de la creciente profundidad de nuestro internamiento en la dirección sugerida por el citado horizonte metafísico de la ética. La más elemental de aquellos tres tipos de tareas, la tarea de lo que lo que cabría llamar una «metafísica elemental» — donde «elemental» no quiere decir en modo alguno «carente de importancia» ni tampoco «desprovista de dificultad»- sería la envuelta en la respuesta (o, por decirlo más modestamente, la envuelta en el intento de responder) a la pregunta por lo real. A despecho de su elementalidad, la pregunta es ciertamente complicada y - a lo largo de la historia de la filosofía - ha dado lugar a todo género de enrevesadas elucubraciones, como la relativa a si la realidad «existe realmente» o la de si lo «realmente real» constituye una realidad de nivel más fundamental que, o de orden superior a, lo que la generalidad de los mortales entiende por «realidad», etcétera. Con el desenfado que le caracteriza, el filósofo esloveno Slavoj Žižek ha relatado su experiencia de asistir a la proyección de la película Matrix (inspirada, según es sabido, en un pensador postmoderno como Baudrillard) desde una localidad cercana a la del espectador ideal de un film así 
- «claramente un idiota», puntualiza - quien se pasó la proyección gimiendo «Oh, Dios mío, luego la realidad no existe...». Pero no sé en verdad si los gemidos de nuestro espectador no se habrían transformado en alaridos en el caso de que Žižek, un suponer, hubiese tratado de explicarle la diferencia existente entre lo que su maestro Lacan entiende por «lo Real» con mayúscula y el óntos ón o «lo entitativamente ente» de Platón, que incluye asimismo un ir y venir de dentro afuera y de fuera adentro de esa sala de cine de la que se nos habla en el mito de la caverna del libro VII de la República...

En cualquier caso, y de acuerdo con la estrategia recomendada por Candel, la metafísica corriente y moliente no necesita convertirse en un galimatías que inescapablemente nos remita, sepultándonos o elevándonos, ni a las insondables honduras del «subsuelo lacaniano» ni a las alturas inaccesibles de los «cielos platónicos», bastando con que nos autorice a mantenernos sencillamente a ras de tierra, que sería también la recomendación que consignamos antes proveniente de la metafísica naturalista de McDowell.

Pero puesto que, al mencionar a esta última, advertimos ya de la conveniencia de prestar atención a la cuestión de los «límites del naturalismo» desde el punto de vista de la ética, tal vez haya llegado ahora el momento de hacernos cargo de ella dentro de este nuestro primer capitulo de la metafísica (de la) moral.

La alusión que acabamos de hacer a Ortega me ha inducido a pensar en la discusión que llevan un par de años manteniendo dos colegas de este país a los cuales profeso a un tiempo admiración intelectual y amistad personal. Se trata de los filósofos Jesús Mosterín (en su libro La naturaleza humana, publicado no hace mucho pero dado en parte a conocer con anterioridad a través de diversos trabajos relacionados con su tema) y Víctor Gómez Pin (en su libro El hombre, un animal singular, donde —al igual que Mosterín en el suyo - retoma y amplía la polémica entre ambos acerca de si el hombre es «un animal más» en la historia evolutiva o si, por el contrario, se trata de un animal cuya singularidad le hace ocupar en ella «un lugar privilegiado»). Frente a esta última tesis, Mosterín — en defensa de lo que considera una posición «naturalista» - escribe: «Cada especie es única, singular e irrepetible; $\mathrm{y}$, desde luego, la especie humana también. Sin embargo, cuando los antinaturalistas proclaman con énfasis retórico y autolaudatorio la singularidad de la especie humana, insistiendo en ciertas características supuestamente únicas de nuestra especie, como el lenguaje, no se limitan a subrayar la trivialidad de que nuestra especie, como cualquier otra, es única y distinta de las demás, sino que pretenden colocarla en un plano superior. Esto es, no sólo sería distinta, sino que iría por delante de las demás, representando algo así como la culminación de la evolución, un planteamiento éste incompatible con la biología evolucionista». Gómez Pin sostendrá en cambio por su parte - frente al naturalismo que tacha de «animalista»— la tesis de la «singularidad» en sentido fuerte de nuestra especie: «De nuevo un fantasma recorre el mundo de la 
cultura dominante, a saber, el fantasma de nuestra pertenencia a la animalidad... La explicación de tal asunción es presentada como un inevitable corolario de lo que la ciencia de nuestra época aporta, de tal manera que las teorías que presentaban al ser humano como jerárquicamente singularizado serían mera expresión de falta de conocimiento respecto a la naturaleza... (Según los naturalistas) habría que dar el paso decisivo de asumir que el hombre carece de toda centralidad en el orden natural, de suerte que los rasgos - como el lenguaje - a los que atribuimos su preeminencia en el seno de la animalidad, o bien no tendrían mayor significación que los que especifican por diferenciación entre distintos animales (el orangután del gorila, por ejemplo) o bien serían tan sólo una más sofisticada expresión de algo que asimismo se da también en diversos otros animales (como la capacidad de comunicarse, por ejemplo, que podrían llegar a desarrollar en términos inapropiadamente calificables de "lingüísticos")». Para nuestros propósitos, y sin perjuicio de retornar más adelante sobre la cuestión de la «especificidad o inespecificidad humana del lenguaje», lo que querría por el momento señalar es que la precedente discusión - cuyo interés en sí misma es innegable- se limitaba a confrontar dos distintas maneras de entender (y de valorar) la naturaleza del ser humano en tanto que animal, singular o no, mientras que lo que a nosotros nos interesa aquí y ahora es otra cosa, a saber, no la contraposición entre dos concepciones de la naturaleza humana, sino la contraposición entre «naturaleza»y "condición» humanas.

A diferencia del concepto de naturaleza (humana o no), que se refiere al mundo fáctico y como tal es de incumbencia de la ciencia (la natural, pero asimismo la social), el concepto de condición humana en cambio es un concepto normativo que no refiere tanto a lo que el mundo es de hecho o a lo que de hecho hay en el mundo (por ejemplo, seres humanos entre otros) cuanto a lo que juzgamos que el mundo debiera ser o debiera haber en el mundo (por ejemplo, seres humanos capaces de elegir entre el lema homo homini lupus - «el hombre es un lobo para el hombre»- que Hobbes tomaría de Plauto o el lema homo homini sacra res — «el hombre es algo sagrado para el hombre»-que ciertos ilustrados repetirían siguiendo a Séneca, una elección esta última entre dos autoconcepciones de la condición humana - las cuales respectivamente desembocan en la conformación de programas de vida no sólo diferentes sino incluso contrapuestos entre sí- de la entera incumbencia de la ética tanto en un caso como en otro).

$\mathrm{Y}$ algo por el estilo me parece que es lo que se esconde no menos tras la célebre, y controvertida, proclamación de Ortega cuando afirma que «el hombre no tiene naturaleza sino que tiene... historia». Ante las protestas de los científicos naturales que se ocupan del hombre, se ha tratado de excusar a Ortega asegurando que lo que en realidad quiso decir es que «la naturaleza humana es histórica», afirmación que encierra sólo una verdad a medias puesto que lo histórico de la naturaleza humana tendría que ser asunto de la 
llamada «historia natural», mientras que lo que a Ortega le interesaba resaltar no era esa historia biológica de los seres humanos sino su historia biográfica, es decir, una historia relativa no a la «naturaleza» sino a la «condición» humana, condición que en definitiva nos permite constituirnos como humanos a través del despliegue narrativo de la identidad que cada quien se va forjando con sus actos en el transcurso de su vida. Mientras que la naturaleza «nos labra» por así decirlo como seres naturales, conformándonos genotípicamente de acuerdo con las instrucciones de nuestro genoma, los seres humanos «nos labramos» en cambio a nosotros mismos desde el punto de vista de la condición humana, autoconformándonos como eso que repetidamente hemos llamado, aun si con discutible pertinencia según vemos ahora, una «segunda naturaleza».

En tanto que sujetos morales que programamos nuestras vidas, no cabe ya pensar que esa programación sea ciega ni inexorablemente dictada por la necesidad natural (de ahí lo inadecuado de aquella fórmula clásica), sino que será incierta y azarosa, es decir, libre (hasta donde hipotéticamente se pueda hablar de «libertad», entendiendo por tal desde la «indeterminación» a la «autodeterminación»); y todo ello, que ya no es - lo repito- puramente «natural», resulta ser «histórico» como Ortega lo presumía, de modo que su dictum podría ser en este punto reformulado haciéndole decir que «el hombre en tanto que animal tiene naturaleza (naturaleza humana, pues no faltaba más), pero además de ello tiene —o trata cuando menos de tenerla, negándose a verse reducido a la pura y simple «animalidad»- condición humana y por ende, y en virtud de ella, tiene en definitiva historia».

Y quizás sea el momento de advertir, a modo de un paréntesis, que es la conciencia de nuestra condición humana la que moralmente nos obliga a solidarizarnos con los animales, comprometiéndonos a otorgarles cuantos derechos sean precisos para garantizar en lo posible su bienestar en este mundo, evitándoles malos tratos y ahorrándoles sufrimientos innecesarios, derechos todos ellos que nunca podrán ser, por descontado, «derechos humanos» - porque ni tan siquiera nuestros parientes próximos los grandes simios son «humanos» y sería absurdo hablar, como se ha hablado, de animals' human rights - pero sí auténticos derechos, legalmente reconocidos y protegidos, que nos impidan comportarnos con ellos inhumanamente, es decir, por debajo de nuestra humana condición en la expresión más alta de esta última (y digo «la más alta» por que, en cotas más bajas, ni tan siquiera está excluida como es obvio la posibilidad de comportarnos inhumanamente con nuestros propios semejantes).

Ahora bien, la persona con la que más y mejor creo haber discutido acerca de los límites de «una ética naturalista» es sin lugar a dudas Ernst Tugendhat - también un viejo amigo además de ilustre filósofo- de quien querría traer a colación un texto suyo relativamente reciente: Moral in evolutionstheoretischer Sicht («La moral en perspectiva evolucionista») recogido en sus 
Aufsätze 1992-2000 del 2001 (colección de ensayos traducida al castellano con el título de «Problemas»). Que yo sepa, Tugendhat es el filósofo contemporáneo no digo ya más preocupado, sino el más obsesionado con el problema de la fundamentación de la ética. Y cuando me correspondió dirigir en funciones el Instituto de Filosofía del CSIC de Madrid tras su refundación a mediados de los años ochenta del siglo pasado, Tugendhat fue invitado en tres ocasiones consecutivas (cada vez que pasaba por Madrid) a dar una conferencia cuyo título, propuesto siempre por él, era una y otra vez el mismo («La fundamentación de la moral») aun cuando no así su contenido, que difería de una ocasión a otra con el escaso intervalo a veces de tan sólo unos meses entre las dos. Y, como prueba de lo que estoy diciendo, invito a quien lo desee a leer los capítulos 6,7 y 8 de la edición española de su libro, en los que sucesivamente se recogen aquellas tres conferencias bajo los títulos respectivos de ¿Qué significa justificar juicios morales? (1998), ¿Cómo debemos entender la moral? (1999) y, finalmente, el ya citado La moral en perspectiva evolucionista (2000) del que sin más dilación paso a ocuparme.

El punto de partida de Tugendhat en este último texto es un conocido pasaje de la Política de Aristóteles en el que éste distingue entre la «voz» (la phoné) y el lenguaje (el lógos) para decirnos a continuación que el ser humano comparte con los animales la primera, la voz, esto es, la posibilidad de emitir sonidos (sonidos que les permiten por igual, tanto a los animales como al ser humano, expresar sensaciones de placer o de dolor), pero se nos dice también que el ser humano - a diferencia ahora del resto de los animaleses el único «animal que dispone de lenguaje» (el único zóon lógon éjon, fórmula ésta griega que sabemos traducible al latín tanto por homo loquens como por homo rationalis), siendo ese lógos — «lenguaje» y/o «razón»— lo que permite al ser humano distinguir entre lo conveniente y lo perjudicial y, en última instancia, entre lo justo y lo injusto (tó dikaion kai tó ádikon).

El gran error, por ejemplo, de los llamados filósofos morales «emotivistas» (como el filósofo analítico Charles Stevenson) consistió, según Tugendhat, en tomar la afirmación de que «algo es justo» o de que «algo es injusto» como equivalente a una interjección que expresara agrado o desagrado (como ¡olé! para expresar «qué agradable» o juf! para expresar «qué desagradable»), lo que acaba reduciendo el comportamiento humano a conducta animal y le priva del lógos (esto es, de la expresión de «por qué» algo le parece bien o mal) para otorgarle sólo la phoné.

Tal y como Tugendhat lo interpreta, lo que el pasaje de Aristóteles vendría a dar entender entonces es que el lenguaje humano es lenguaje proposicional o enunciativo, esto es, se halla dotado de una estructuración que le permite expresar como proposiciones opiniones y deseos («Opino que tal y tal cosa es justa»o «Deseo que tal y tal cosa se realice, o sea, deseo que se haga justicia»); y ello obliga a quien se sirve del lenguaje a esos efectos a deliberar, es decir, a «dar razón» (lógon didónai, recordemos) de lo que opina o de 
lo que desea, ya sean razones en pro de tales opiniones, ya sean razones en contra de su interlocutor si las deniega, esto es, si no opina que esa cosa sea justa o no desea que se realice.

Así entendido, añade Tugendhat, «el lenguaje representa una ventaja evolutiva,..., y se puede entender como la base de una evolución propia que no sería ya genética». En cuanto a aquella previa evolución genética de nuestro lenguaje, la hipótesis más plausible acerca de la filogénesis del lenguaje apunta hoy a una maduración lenta y gradual de las capacidades cognitivas de nuestro phylum biológico, acompañada de un salto último acontecido con nuestra especie, en la que el hecho de contar con un aparato fonador muy preciso le habría permitido realizar «enlaces fonético-semánticos de doble articulación», a saber, echando mano de una primera articulación que nos permita transformar series de sonidos (vocales y consonantes) en palabras y de una segunda articulación que - tras haber dotado a esas palabras de significadonos permita transformar luego series de palabras en frases. Todo lo cual persigue, ciertamente, un propósito comunicativo, pero donde la comunicación se da también naturalmente, en un mayor o menor grado, en otros animales, mientras que lo verdaderamente específico del lenguaje humano - es decir, de todo lenguaje humano, puesto que todas las lenguas parecen responder a una misma conformación de acuerdo con la teoría lingüística chomskyanavendría a ser, desde un punto de vista sintáctico, la posibilidad de generar una cantidad virtualmente infinita de mensajes a partir de elementos finitos (como un vocabulario y una serie de reglas gramaticales); $y$, desde un punto de vista semántico-pragmático, lo decisivo sería ahora el hecho de posibilitar - a través de la introducción del pensamiento deliberativo - un desarrollo de la racionalidad que no se halla genéticamente condicionado y abre paso a un género de evolución cultural que no admite tampoco parangón con las llamadas «culturas animales».

A la base de semejante «racionalidad» se encuentra por otra parte el hecho de que, como le gusta a Tugendhat recordárnoslo, los seres humanos no somos «de alambre rígido» (no somos hard-wired) y, cuando abordamos racionalmente una opinión o un deseo (y, consecuentemente, una acción), nos encontramos siempre ante una «diversidad de opciones» (por lo pronto, la del sí y la del $n o$ ) que es lo que nos lleva a «concebirnos como libres»... siquiera en el sentido de que nuestra conducta no responde aparentemente a ningún estricto determinismo causal, ni innato ni adquirido mediante aprendizaje.

Todo lo cual, como a cualquiera se le alcanza, reviste una importancia crucial para la reflexión sobre la moralidad, toda vez que — por interesante que resulte el estudio de la «filogénesis de la moral» humana, que ha dado pie a algún sociobiólogo para subrayar (y exagerar, cuando no incluso extrapolar) la continuidad entre ciertos patrones de comportamiento animal y humano, como en el caso de los llamados «altruísmo y egoísmo evolutivos o genéticos» (pensemos en El gen egoísta de Richard Dawkins) y lo que de ordinario 
solemos entender por «altruísmo y egoísmo en sentido moral»— la moral humana no puede, pese a ello, ser exhaustivamente explicada ni mucho menos justificada o fundamentada «en términos filogenéticos», esto es, no cabe dar filogenéticamente cuenta de multitud de aspectos, muchos de ellos elementales, de la compleja fenomenología de la moral humana, comenzando por fenómenos tales como los sentimientos de obligación moral (o de culpabilidad en caso de su infracción o incumplimiento) que a nuestros primos hermanos los grandes simios, antes aludidos, parecen serles desconocidos... lo que sin duda los convierte en inocentes en una medida en que nosotros no podemos ya serlo.

Retornando al pasaje de la Política de Aristóteles invocado por Tugendhat, su autor relacionaba allí el lógos (esto es, el lenguaje y también - como hasta la saciedad venimos repitiéndolo - la razón y, generalizando, el pensamiento) con esas formas de comunidad que son «la casa» (el óikos) y la «ciudad» (la pólis). Y, en una vena parecida a ésa, Tugendhat va a insistir también en la importancia de esas o parecidas formas de comunidad para la génesis (la génesis social, no ya la puramente natural) de la moral, pero dando ahora un paso más y buscando en ellas también su justificación filosófica. En cuanto a lo primero - lo que podríamos llamar, aplicando a la ética una célebre distinción del filósofo de la ciencia Hans Reichenbach, el «contexto de descubrimiento» en cuanto diferente del «contexto de justificación»- parece claro que sin comunidad humana no hay moralidad: al Robinson de De Foe no se le suscitan problemas morales hasta la aparición de Viernes en la isla, pues no parece que la convivencia con la cabra le plantease ninguno (a diferencia, ciertamente, del protagonista de la obra de ese título, La cabra, del dramaturgo Edward Albee), pero ¿qué pasa con el «contexto de justificación»? De acuerdo con lo dicho, Reichenbach acostumbraba a distinguir entre el descubrimiento de una idea científica - como la fórmula de la estructura molecular del benceno, que se le ocurrió a Kekulé mientras dormitaba amodorrado frente a la chimenea encendida de su estudio, creyendo ver entre las llamas la temblorosa figura de una serpiente mordiéndose la cola que inmediatamente asoció con la distribución en un anillo hexagonal de los seis átomos de carbono integrantes de la molécula bencénica-y la justificación de dicha idea mediante el ulterior proceso de experimentación llamado a corroborar su descubrimiento. Y por lo que a la justificación en la ética concierne, Tugendhat atribuye el respeto a las normas (lo normativo, como sabemos, parece constituir un fenómeno exclusivamente humano) a sentimientos sociales de vergüenza o de culpa que impedirían al individuo transgredir el código moral de la comunidad. Mas preguntémonos de nuevo: ¿y si esos «sentimientos» no se dan? En trabajos anteriores al que estamos ahora comentado, Tugendhat ha hablado de lo que llama un lack of moral sense, una «falta de sentido moral» que descalificaría al individuo como sujeto moral. Pero la expresión moral sense, de la que Darwin se sirvió en su libro sobre El origen del hombre, no 
puede aquí tener un significado puramente biológico, en cuyo caso carecería de relevancia propiamente moral; y, si se trata simplemente del resultado de la presión social (que es como parece que lo entiende Tugendhat), no hay que olvidar que en ocasiones parece revestir mayor valor moral la resistencia a esa presión social por parte del individuo que su sometimiento a ella, como la historia de la literatura nos lo recuerda desde la Antígona de Sófocles a Un enemigo del pueblo de Ibsen, por no citar sino un par de rebeldes morales conocidos.

Cuando se nos habla por consiguiente de justificación (o de fundamentación) de la moral, no suele quedar claro - y tampoco lo está, a mi parecer, en el caso de Tugendhat - si con el vocablo «moral» nos estamos refiriendo o bien, en primer término, a una pauta de comportamiento común a todos los miembros de la especie humana; o bien, en segundo término, al código de conducta vigente en una determinada comunidad sociohistóricamente dada; o bien, en tercer término, a los dictados de la conciencia moral individual (tres significados de nuestro vocablo que se hallan, en cambio, nítidamente explicitados en la triple distinción de Aranguren - ya clásica en la filosofía moral de lengua española - entre, por ese orden, moral como «estructura», moral como «contenido» y moral como «actitud»).

La noción de «moral como estructura», para empezar por ella, sería la que mejor recoge lo que tal vez cabría llamar en términos de Tugendhat la hard-wiredlessness o «ausencia de la condición de alambre rígido» que caracteriza a los miembros de nuestra especie. De acuerdo con Aranguren, el esquema estímulo-respuesta no basta con su rigidez o su automatismo para dar cuenta de la conducta humana por mucho que se empeñen en ello los conductistas radicales, puesto que los seres humanos no se hallan gobernados por sus ferencias o «impulsos biológicos», sino que tienen pre-ferencias que en diversa medida les permiten jerarquizarlos. Y hoy en rigor sabemos, gracias a Harry Frankfurt, que nos es dado incluso «preferir nuestras preferencias» gracias a preferencias (o metapreferencias) de diverso orden: yo puedo preferir (preferencia de "primer orden») fumar a no-fumar desde el punto de vista de mis apetencias; pero además de eso, y por razones de salud, puedo preferir (preferencia de "segundo orden») la abstinencia al tabaquismo; y así, en efecto, lo preferiré... si es que prefiero (preferencia, en fin, de «tercer orden») demorar por un tiempo, en lugar de precipitarla, mi partida de este perro mundo. $\mathrm{Y}$ el hecho de que tengamos preferencias, lo que de algún modo nos lleva a presumir que somos libres de preferir esto o lo otro, determina que el ser humano sea estructuralmente, o constitutivamente, moral, lo que quiere decir literalmente que «no puede dejar de ser moral» y que, salvo en casos patológicos (el caso de un psicópata o simplemente el de la víctima de un rapto de locura), no puede ser amoral. Que es lo que, en términos más clásicos, llamaban los escolásticos la moralitas in genere o el genus moris, es decir, la moralidad que genéricamente se contrapone a la a-moralidad, contraposición ésta 
previa a la ulterior contraposición, más específica, entre moralidad e in-moralidad.

Pero con esto ya pasamos a la «moral como contenido». Por el hecho de preferir en virtud de nuestra estructura o nuestra constitución moral, los seres humanos somos presumiblemente libres y, por ende, morales. Pero, a partir de ahí, nuestras preferencias podrían recaer tanto sobre contenidos «morales» como sobre contenidos «inmorales». Y mientras que nuestra constitución moral permanece a grandes rasgos invariable tras haber sido conquistada al cabo de largos siglos de evolución natural, los contenidos morales o inmorales de que estamos hablando ahora han solido y suelen variar de unas épocas a otras, así como de unos lugares a otros, toda vez que - en tanto que usos y costumbres morales, o códigos morales, o formas morales de vida, etcéteratales contenidos se hallan sociohistóricamente condicionados. Y cuando Tugendhat afirma, como lo hace en más de una ocasión, que nuestras normas morales nos vienen dadas a través de la comunidad de la que formamos parte, podría pensarse que está erigiendo a esta última en la fuente suprema de esa nuestra «moral como contenido». Pero lo que sucede es que nosotros, que no somos «de alambre rígido» por naturaleza, tampoco lo somos por la presión social y podemos en consecuencia cuestionar esos contenidos, negándonos en definitiva a hacerlos nuestros.

Y con ello - tras haber pasado por el nivel de la especie humana y luego por el de la comunidad sociohistórica - llegaríamos al nivel irreductiblemente individual que se halla a la base de toda moralidad. Es decir, al nivel de la «moral como actitud». La libertad de la que presumíamos nos daba, como hemos visto, la oportunidad de preferir o de elegir entre contenidos morales o inmorales, pero también, claro está, la de equivocarnos moralmente; y sin por ello exonerarnos de responsabilidad por nuestros errores morales, como individuos tenemos también derecho a ser juzgados - y hasta a juzgarnos a nosotros mismos (lo que naturalmente conlleva con frecuencia el riesgo del autoengaño o, cuando menos, el de la autoindulgencia) - por la honesta intención con que tratamos de aproximar nuestra voluntad a lo que creemos que es la ley moral. La moral como actitud sería, pues, otro nombre para aquello que Kant llamó «la buena voluntad». Una voluntad que - más acorde con lo que podríamos llamar ahora la voluntad de potencia que con la voluntad de poder en términos nietzscheanos - cabría llamar tal vez por nuestra parte voluntad de moralidad.

En cuanto a la pregunta acerca de cómo habrían de «articularse» entre sí los «tres niveles morales» reseñados desde el punto de vista que los congrega de la «justificación moral», me limitaré a proponer un par de ejemplos que nos permitan tratar de aventurar una respuesta. El primero tendría que ver con la cuestión del «relativismo»y el «absolutismo» morales, ya abordada en el capítulo precedente bajo la forma de una contraposición entre el contextualismo y el universalismo que de algún modo la ejemplifican. Y el segundo ven- 
dría a ahondar en aquella misma cuestión, pero replanteada ahora «en el tiempo», más bien que «en el espacio», bajo la forma de una interrogación acerca de la posibilidad o imposibilidad de un progreso moral.

Por lo que se refiere al primer ejemplo, y dentro de esa variedad de relativismo o de contextualismo representada por el comunitarismo, los comunitaristas radicales acostumbran a insistir en que el aprendizaje de la moral - a diferencia del aprendizaje de la matemática, cuyos contenidos resultan ser máximamente universales - se daría siempre contextualizado en el seno de una comunidad. En contraste con quienes aprenden las reglas de la matemática, nadie aprende las reglas de la moral, sino tan sólo las de una moral determinada, a saber, las de la moral vigente en $s u$ comunidad. De suerte que, si se priva a alguien de esta última, no habría razón para que ese alguien se comportara moralmente. Ahora bien, el comunitarista que razone de esa manera olvida, por lo pronto, que hay un sentido en el que todo ser humano se comporta «moralmente» (puesto que no lo puede hacer «amoralmente»), a saber, en el plano de la «moral como estructura». Pero tampoco en el plano de la «moral como contenido» tendrían sus argumentos demasiado peso. Es cierto, desde luego, que el aprendizaje de la moral no se parece gran cosa al de la matemática, cuya «universalidad» sin restricciones no admite parangón con el caso de la moral. Pero pensemos en un analogado más a nuestra medida, como vendría a ser el caso del lenguaje, esto es, el del aprendizaje de una lengua como pudiera ser la nuestra. Cuando aprendemos nuestra lengua, lo que aprendemos es «una» lengua y no «el» lenguaje, tal y como aprendemos «una» moral y no «la» moral. No obstante, y si nos fijamos bien, lo que aprendemos cuando aprendemos nuestra lengua es a «comunicarnos» mediante ella y, por lo tanto, mediante cualquier otra lengua que aprendamos a partir de ella o desde ella. Y algo muy semejante es lo que ocurre cuando aprendemos la moral de «nuestra» particular comunidad. En tal caso aprendemos a «comportarnos moralmente», aprendizaje que podremos reproducir en cualquier otro contexto moral en el que nos hallemos insertos o nos imaginemos que lo estamos. Y eso será en definitiva lo que nos permita tomar distancia respecto de nuestra propia forma moral de vida, así como compararla con otras «formas morales de vida alternativas» entre las cuales elegir o preferir. En cuanto a semejante elección o preferencia, a lo más que cabría aspirar es a que se halle presidida por la «voluntad de moralidad» de la que hablábamos, lo que nos sitúa finalmente en el nivel de la «moral como actitud» que tiene como guía a la conciencia individual y vendría a corresponderse con lo que el psicólogo de la moral Lawrence Kohlberg dio en llamar el «nivel de la postconvencionalidad». Es decir, aquel nivel en el que, como individuos, podemos sentirnos obligados a romper con los mores o «convenciones» morales de nuestra comunidad cuando esas convenciones conflictúan con nuestros propias convicciones o principios morales, como en el caso, supongamos, de una comunidad racista dentro de la que no se respetaran los derechos humanos de otras etnias. 
Vayamos ahora con nuestro segundo ejemplo, relativo a la cuestión del progreso moral. Alguna vez se ha dicho que «el grado más bajo» en tal progreso vino a quedar establecido cuando un hombre mató a otro y que «el grado más alto» se alcanzó cuando un hombre dio su vida por otro; y que los dos acontecimientos tuvieron lugar «simultáneamente», a saber, en el $\mathrm{Pa}$ leolítico. Dicho de otra manera, una vez alcanzado el plano evolutivo de la «moral como estructura» no parece que puedan registrarse grandes cambios en la constitución moral de los seres humanos, que es - dicho sea en un inciso - lo que hoy nos permite que sigamos entendiendo la tragedia griega y metiéndonos dentro de sus personajes. Pero de ahí no se sigue que nada haya cambiado en lo concerniente a la moralidad desde el Paleolítico a nuestros días. Como nosotros ya sabemos, la «moral como estructura» entraña la presunción de la libertad humana, y el primitivo ahormado por su horda era sin duda menos libre que nosotros tanto cuando se ejercitaba en la ayuda mutua como cuando lo hacía en la mutua destrucción; sin olvidar que no menos han evolucionado desde entonces los medios con que contamos para llevar a cabo una cosa u otra. De la misma manera, pues, que ha habido un indudable progreso científico-técnico que nos permite hoy tanto salvar como aniquilar millones de vidas de nuestros semejantes, también parece haber habido un "progreso de la libertad» a la hora de decidirnos a elegir o preferir entre ambos cursos de acción, el cooperativo y el exterminador. $Y$ ése acaso sea el progreso que quepa registrar en el plano de la «moral como contenido», esto es, el progreso de los contenidos de la moral que se registra, por ejemplo, a través de la progresiva implantación - desde la Ilustración en adelante - de los «derechos humanos» citados hace un momento. Pero, si ha habido un tal progreso, de lo que ciertamente no se trata es de un progreso irreversible, esto es, no está excluida la posibilidad de retrocesos, de los que hemos tenido muestras abundantísimas en un siglo como el pasado, plagado, como llevamos diciendo una vez y otra, de catástrofes o más exactamente de «calamidades», que es como Ernesto Garzón Valdés gusta de referirse a las catástrofes que nos incumben moralmente. Y, como antes, nuestro progreso o nuestro retroceso dependerá de nuestra voluntad de moralidad y, por lo tanto, de la individualización de esa moralidad, es decir, de los individuos que son los habitantes de este nivel o plano de la moral que es la «moral como actitud» y que, por habitarlo, son los únicos que merecen la condición de sujetos morales, o sea la condición de auténticos e insustituibles protagonistas de la vida moral.

Y con ello habremos llegado a lo que podríamos llamar el corazón metafísico de la ética o, lo que viene a ser lo mismo, el meollo de la metafísica (de la) moral... que no es otro que la presuposición de la libertad de los sujetos morales, libertad a la que hasta aquí nos hemos venido refiriendo por medio de adjetivos como «aparente», «hipotética» o «presumible»... a falta, como es obvio, de una fehaciente comprobación de su existencia. 
En su libro The Ethical Brain («El cerebro ético»), el profesor Michael Gazzaniga - eminente neurocientífico y uno de los padres de la llamada «neuroética» (esto es, de la reflexión moral sobre la conducta humana a partir de la neurociencia cognitiva) que, al igual que otros científicos como el biólogo Stephen Jay Gould, contempla con alguna aprensión la idea de un determinismo radical que no deje lugar a la libertad humana - confiesa con desaliento la dificultad de ofrecer por vía experimental un argumento decisivo en favor de esta última, tras hacer ver que si queremos hoy analizar la «cuestión del libre albedrío», o voluntad libre (free will), hay que investigar el cerebro y preguntarse si éste es «un órgano determinista» (un órgano configurado genéticamente para llevar a cabo acciones sobre las que no tenemos control) o si, por el contrario, es el lugar donde alojar a «un fantasma indeterminista» (el célebre ghost in the machine o «fantasma en la máquina», como lo bautizó el filósofo Gilbert Ryle), un fantasma llamado mente que nos facultaría para obrar libremente. Con la finalidad de permitir inclinarnos en un sentido u otro de semejante disyuntiva, se diseñó en su día el conocido experimento de Benjamin Libet destinado a medir la actividad cerebral que se produce durante un movimiento supuestamente voluntario de la mano, un movimiento no reflejo, supongamos, consistente en poner en nuestra muñeca el reloj en hora. Si el cerebro se adelantase a desarrollar enteramente su función antes de que el sujeto del experimento sea consciente de su decisión de llevar a cabo dicha acción en el momento de iniciarse esta última, se impondría el determinismo, pues difícilmente cabría atribuir voluntariedad en ese caso a la decisión en cuestión. Pero la situación sería, en cambio, muy distinta si el sujeto del experimento tuviese un cierto margen para decidir consciente y voluntariamente realizar o no la acción prevista, en cuyo caso se impondría, si no la victoria de la mente, al menos sí la de la libertad frente a los dictados del cerebro. Libet averiguó en su experimento que, con antelación al movimiento de la mano (unos 500 milisegundos antes), se registraba ya una actividad cerebral preparatoria del citado movimiento, así como que el tiempo transcurrido entre el desencadenamiento de la actividad cerebral y el momento mismo de la decisión consciente o inconsciente de mover o no la mano era de unos 300 milisegundos, mientras que la señal neural tardaba a su vez alrededor de 100 milisegundos en viajar desde el cerebro a la mano, de modo que apenas restarían unos 100 milisegundos escasos para que el yo consciente siga adelante con la decisión inconsciente de mover aquélla (en cuyo caso ganaría el cerebro y, por ende, el determinismo) o por el contrario la vete (en cuyo caso ganaría, si no tal vez la mente, al menos sí de nuevo la libertad). Pero éste es en verdad un margen decididamente estrecho para poder dar por zanjada la disputa, disputa que vendría a quedar en tablas si es que la situación no se asemeja a la proverbial irresolución de la discusión acerca de la botella dada por medio llena o por medio vacía...

Aun si se trata de casos evidentemente distintos, la situación descrita guarda un cierto parecido con la planteada en la famosa antinomia de la cau- 
salidad y la libertad de la primera de las Críticas de Kant. Como es bien sabido, la antinomia kantiana vendría a dejarse formular en los siguientes términos: al igual que los restantes acontecimientos de este mundo — se diría - las acciones humanas tienen que poder ser explicadas causalmente; pero, a diferencia del resto de los seres de este mundo, los hombres acostumbran a considerarse a sí mismos como libres. Quien haga suya la tesis de la libertad, renunciará a la posibilidad de suministrar una explicación causal de las acciones humanas mientras deja en cambio la puerta abierta a la moralidad de esas acciones, mas para quien se instale en la antitesis del determinismo universal — que hacía posible la ciencia de la época - la libertad, y consiguientemente la moralidad, no pasarán de ser un sueño.

Sin embargo, la diferencia entre los planteamientos de Kant y de Gazzaniga, cualesquiera que puedan ser las semejanzas entre ambos, estriba en que Gazzaniga —un científico - apela por su parte a la comprobación empírica (exitosa o fallida, cosa que no hace al caso ahora), mientras que lo que Kant advierte es que la libertad desde un punto de vista ético (lo mismo, por lo demás, que la causalidad, que tampoco es ahora lo que nos interesa) no es algo que haya que dar por empíricamente comprobado sino por «presupuesto» (vorausgesetzt, escribe Kant literalmente) si queremos hablar «en términos morales», esto es, se trata de una presuposición (una Voraussetzung), y una presuposición absoluta, de la metafisica (de la) moral: sin libertad no habría ética para la filosofía trascendental kantiana (aquella que se interesaba, según vimos en su momento, por las «condiciones de posibilidad de lo real», en nuestro caso las «condiciones de posibilidad de la moral») y de ahí que tengamos que dar la libertad por «presupuesta», por «absolutamente presupuesta», si es que queremos que haya ética.

Lo que llamara Kant la «libertad trascendental» no es, por tanto, lo mismo que «la libertad empírica». Esta última «admite grados», como cuando decíamos antes que el primitivo ahormado por su horda era sin duda menos libre de lo que podemos serlo nosotros hoy en día. Pero, trascendentalmente hablando, no entran en juego gradaciones, sino se es libre o no se es... si es que queremos ser (y en esto consiste la libertad así entendida) sujetos y no objetos, esto es, cosas. Como yo mismo he señalado alguna vez, nosotros siempre podemos conceder a los demás lo que cabría llamar «el beneficio de la causalidad», es decir, excusarles por sus malas acciones alegando que se hallaban determinadas por su deficiente educación social, por los traumas psíquicos de su infancia o por los estragos de la programación de su cerebro reptiliano. Pero nunca podré hacer eso conmigo mismo a título de excusa sin incurrir en lo que Sartre llamaba la «mala fe» y yo preferiría llamar la «mala voluntad», esto es, sin renunciar a considerarme a mí mismo como un sujeto moral y rebajarme a ser una cosa más entre las cosas, renunciando así a mi condición humana.

Condición que, una vez perdida, no la podré recuperar gracias al beneficio de la causalidad que otros me concedan, sino responsabilizándome hu- 
manamente de mis propias acciones y tratando de reparar las consecuencias dañosas para los demás de aquellas últimas, es decir, haciendo «un buen uso» de la «libertad» antes malgastada en lugar de negarla «al precio de la cosificación».

Y lo que acaba de decirse del mal originado por la acción individual de cada quien se extenderá parejamente al «mal social» resultante de las interacciones colectivas de los seres humanos, cuya reparación obliga a preguntarnos no ya, o no sólo, por las condiciones de posibilidad de lo real (como si la realidad tal cual es estuviera ya completada para siempre y fuera además de ello inamovible) sino no menos por las condiciones de realización de lo posible, entendiendo por tal no sólo aquello que la realidad es o aquello que hay en la realidad, sino asimismo aquello que pensamos que la realidad debiera ser o debiera haber en la realidad.

Pero con ello entramos ya en el segundo capitulo o segundo grupo de preguntas de la metafísica (de la) moral, «capítulo» al que, por razones de espacio y tiempo, no podremos prestar tanta atención como al capítulo precedente; y «grupo de preguntas» a las cuales cabría acoger ahora conjuntamente bajo el epígrafe de la pregunta por «lo posible», una pregunta ésta que nos conduce un paso adelante de la pregunta por «lo real» característica de la «metafísica de cercanías» en que veníamos moviéndonos y que - sin llegar todavía a la «metafísica de lejanías» de la pregunta «sin respuesta»— nos ubica por el momento en lo que sería dado llamar, como aventuramos con anterioridad, la «metafísica de la distancia media». La pregunta por lo real vendría a ser la pregunta cuya respuesta corre a cargo de ese capítulo de la metafísica que tradicionalmente se conoce por ontología (caracterizada, desde Aristóteles a Quine, por la reflexión acerca de lo que «es» o lo que «hay»), pero la metafísica - y, desde luego, la metafísica (de la) moral- no se reduce a ontología, como desde diversos ángulos han insistido en sostener contemporáneamente filósofos tan dispares como Emmanuel Levinas o Hilary Putnam, pasando en nuestra lengua por Xavier Zubiri. Que la metafísica no se reduzca a ontología para nada implica, sin embargo, que postule una «super-realidad» allende el «mundo real» a la manera del mundo de las ideas platónicas... o, en el caso de la metafísica (de la) moral, un mundo del deber ser allende el mundo del ser.

Tal y como, en nuestros días, vendrían por ejemplo a planteársela los 1lamados «movimientos altermundistas», la pregunta por lo posible no descarta, en efecto, la posibilidad de «un mundo otro» o «un otro mundo»... pero siempre que dichos mundos «estén en éste», como tendría que estarlo, por lo pronto, el «mundo del deber ser», mundo que nace de nuestra radical insatisfacción o «nuestro descontento» - como le hacía decir Antonio Machado a su heterónimo Juan de Mairena - con lo que el mundo «es» (o «no es») o con lo que «hay» (o «no hay») en el mundo, descontento que nos induce a «preguntarnos por la posibilidad» de cambiarlo y construir a partir de él un mundo mejor. 
La pregunta por lo posible hermana así a la ética con lo que se conoce como «el pensamiento utópico», un pensamiento cuyo representante por antonomasia a lo largo del siglo XX —a saber, el pensador marxista Ernst Bloch - se empeñó en «ontologizar» indebidamente, tratando de mezclar su filosofía moral - que Bloch bautizaría como una «ontología del no-ser-todavía (noch-nicht-sein)» y nosotros podríamos traducir por una «metafísica moral de lo posible»- con una «ontología del ser definitivamente realizado» a impulsos de una filosofía escatológica de la historia dominada por la idea hegeliana del «fin de la historia» misma. Es decir, Bloch hacía culminar a dicha historia con un «punto final» o éschaton, el cual sería además un happy end - esto es, un «final feliz» consistente en la consumación de la Revolución social con mayúscula (lo que Bloch dio en llamar el utopissimum) — con cuyo logro la historia podría considerar al fin conclusa su ardua travesía tras haber coronado para siempre la lucha de la humanidad por conquistar la plenitud en el desarrollo de sus potencialidades. Aunque, a decir verdad, Bloch fue lo suficientemente clarividente como para reconocer — bastantes años antes de la caída del muro de Berlín y el subsiguiente colapso de la Unión Soviéticaque el llamado «socialismo real» se hallaba lejos de constituir el mejor escenario sobre el que proceder a representar ante la humanidad la materialización de ningún utopissimum, si es que no había incluso que temer que semejante socialismo real — siempre bastante más «real» que «socialista»ganase de hecho la partida, obligando de paso al pensamiento utópico a digerir «utopemas» del calibre del Gulag y otras conquistas de los años de plomo del estalinismo.

Y en cuanto a la utopía, ¿qué habremos de entender por «utopía»? Como todo el mundo sabe, Thomas More (Tomás Moro) compuso irónicamente el título de su obra Utopia a base de los vocablos griegos ou y tópos, a traducir por «en ningún sitio», Nowhere en la traducción inglesa del texto latino del propio siglo XVI o «no hay tal lugar», como en el XVII traduciría Quevedo entre nosotros. Alguna vez se ha dicho, afirmación sin duda discutible, que si el único sentido del término «utopía» fuera su sentido literal, la utopía sería indiscernible de la ucronía, pues decir de algo que no ha tenido, tiene ni tendrá jamás lugar vendría a ser lo mismo que decir que está fuera del tiempo. Lo que explica la tendencia, cuando no a confundirlas, al menos a asociar utopía y ucronía como igualmente ajenas y hasta «contrarias a los hechos», que se suponen todos temporales. El término «ucronía» fue en efecto utilizado por algún filósofo del siglo XIX, como Charles Renouvier, para referirse a la posible - 0 , mejor dicho, imposible - desviación del curso de la historia por obra de acontecimientos que no han llegado de hecho a producirse, como cuando se habla de «lo que hubiera pasado si...» - por ejemplo, «lo que hubiera pasado si Stalin no llega a hacerse con el poder en la Unión Soviética»- dando pie, de este modo, a la construcción de los llamados «condicionales contrafácticos» del tipo de «Si Stalin no llega a hacerse con el poder, entonces...». Excepción he- 
cha acaso de los cultivadores de lo que hoy se conoce como «historia virtual» - actualmente tan en boga a título de divertimento - los historiadores han solido desconfiar de semejante contrafacticidad ucrónica, considerándola una fuente de especulaciones ociosas sobre un pasado irreversible, lo que constituiría ya una razón de cierto peso para procurar distinguirla de la contrafacticidad utópica, en la que el acento se desplaza del pasado al futuro, es decir, de la reflexión sobre «lo que hubiera pasado si...» a la reflexión sobre «lo que pasaría si...». Y si atendemos a lo que Arnhelm Neusüss ha llamado «el concepto intencional de utopía», esto es, a la intención utópica que anima cualquier proyecto de transformar el mundo, habría que concederle que la reflexión acerca de «lo que pasaría si...» pudiera estar guiada por consideraciones relativas a «la realización de determinados ideales sociales» que - además de implicar inexcusablemente a la ética - inducen a pensar que, tanto o más que por su «contrafacticidad», la utopía vendría a dejarse caracterizar por su sed de facticidad y apunta así a nuevos tópoi o «lugares» que, además de deseables, se presumen asequibles o, cuando menos, se está lejos de considerar por principio inasequibles, por más larga y dificultosa que haya de ser la ruta que nos conduzca hasta ellos. Todo eso es muy cierto y campea a lo largo de la obra de Bloch — desde su primer libro Geist der Utopie («El espíritu de la utopía») de 1918 a su libro capital Das Prinzip Hoffnung («El principio de la esperanza» o «La esperanza como principio») de 1954, en los que Bloch sentará, frente a Engels, la primacía del «socialismo utópico» sobre el «socialismo científico»-, pero insisto por mi parte en advertir contra el peligro de que, a pesar de todos los pesares, la utopía blochiana degenere a la postre en utopía escatológica.

Etimológicamente hablando, la utopía o lo «u-tópico» se opone a la topía o a lo «tópico», esto es, a lo consabido y lo consolidado, a lo incuestionablemente dado, a lo tenido por insusceptible de cambio, frente a todo lo cual la utopía «abre la historia» a la irrupción en ella de la «novedad». Pero Bloch, a quien nadie se atrevería a negarle su sensibilidad para lo novum, acabará por identificarlo con un ultimum (que es lo que en latín significa el vocablo griego éschaton, del que procede en nuestro idioma «escatología»). Con lo que la utopía así entendida, esto es, entendida como «utopía escatológica», vendría a resultar infiel a su mismísima etimología y supondría ni más ni menos que «el cierre de la historia», tanto si el tópos o «lugar» que constituye su final resulta ser un final feliz (una eu-topía o «buen lugar») como si resulta ser un final aciago (una dys-topía o «mal lugar», esto es, una disutopía).

Y lo que frente a semejante degeneración de la utopía tendría que proponer la metafísica (de la) moral, en su intento de responder a «la pregunta por lo posible», es la insistencia en concebir a la historia como un proceso no sólo inconcluso sino muy presumiblemente inconcluíble, reivindicando así la fidelidad a la etimología originaria del vocablo «utopía», tal y como dicha fidelidad resplandecía en la interpretación que Aranguren gustaba dar de la metáfora del «compañero de viaje», tan popular en otros tiempos en los que, al 
parecer, había viajes, así como viajeros dispuestos a acompañarlos: "Contra lo que a veces se ha pensando» - escribiría Aranguren al respecto- «al compañero de viaje no se le obligaba a subir al tren ni tampoco se le llevaba adonde no quisiese ir. Antes bien, y en aras de un realismo político que nunca ha vacilado en conculcar los más excelsos ideales, se le instaba a apearse en cada una de las estaciones del itinerario, invocando para ello razones de estrategia política u oportunidad táctica con las que persuadirle de que ya había llegado a la estación final. Pero el genuino compañero de viaje se negaba obstinadamente a bajar y continuaba adelante su trayecto, soñando con alcanzar, pero sin alcanzarla nunca, la anhelada meta con que darlo por concluido. El nombre de esa meta o esa estación final no era otro que Nowhere, esto es, ningún lugar, que es justamente lo que utopía quiere decir».

Por lo que se refiere ahora al modelo de los que cabría llamar ideales utópicos no-escatológicos, la historia habrá de concebirse, lo repito, como un proceso inconcluso e inconcluible... cuyos protagonistas - a saber, individuos y grupos de individuos - no pueden aspirar por eso mismo a «controlarlo en su totalidad», salvo que se arriesguen (como más de una vez le ha sido reprochado al marxismo o, por lo menos, a un cierto marxismo) a confundir predicciones con profecías, por un lado, y planificaciones racionales de la acción con taumaturgias por el otro. A diferencia de las «profecías», las «predicciones» o pronósticos formulan conjeturas empíricamente controlables acerca de la evolución de determinadas tendencias sociales observadas, pero siempre a lo largo de un período limitado de tiempo. Y a diferencia de los «taumaturgias» que prodigiosa o milagrosamente remiten a la consumación de los tiempos, las «planificaciones» o programas racionales de acción confeccionan a su vez propuestas a seguir con la finalidad de proveer los medios más adecuados para el logro futuro - sea a corto, medio o largo plazo, pero un plazo de nuevo temporalmente limitado - de una serie de objetivos políticos.

Ahora bien, tanto la predicción o la prognosis como la planificación o la programación son tareas que forman parte de esa actividad conocida como «ingeniería sociopolítica» (social and political engineering) y que - por muy respetables que sean, como no hay duda de que lo son- no bastan, sostengan lo que sostengan Popper y los popperianos, para reemplazar o hacerse cargo de las funciones a desempeñar por los «ideales utópicos no-escatológicos» de que antes hablábamos, los cuales no necesitan remitir a la consumación de los tiempos para gozar de una implantación temporal en la historia más distendida y duradera que la de esas otras expectativas y metas, tácticas o estratégicas, de carácter un tanto más puntual o ingenieril.

Y de ahí, en mi opinión, la no demasiado apropiada titulación de un libro inteligente de un autor asimismo inteligente, como mi buen amigo Juan Antonio Rivera, que reza Menos utopía y más libertad... sin reparar en que la libertad social y política (susceptible de gradación en cuanto variedad de la 
«libertad empírica» que antes veíamos) no deja a su vez de ser un «ideal utópico» inexhaustible en tanto que «no-escatológico», pero asimismo irreductible a un objetivo puro y simple de la ingeniería sociopolítica como vendrían a serlo la reducción de impuestos o la subida de la tasa de interés (y otro tanto cabría decir del ideal de la igualdad).

Pero por si la diferencia entre una cosa y otra no quedase del todo clara, vayan aquí tres ejemplos más de tales ideales utópicos no-escatológicos.

El primero de ellos sería el de la paz, que constituye ciertamente una utopía y no es nada seguro que algún día podamos disfrutarla en plenitud ni mucho menos a perpetuidad. Como es bien sabido, la única paz verdaderamente perpetua sería la de los cementerios y no es casual que la inspiración del título de la obra de Kant se debiese al grabado de un camposanto que acompañaba al rótulo de La paz perpetua en la fachada de una posada holandesa. En cuanto al texto de Kant, su título exacto no era aquél sino «Hacia la paz perpetua» (Zum ewigen Frieden), como dando a entender que la paz perpetua era algo por conquistar más bien que una conquista consumada. Y de ahí que la traducción más adecuada del título de Kant sea para mí la del filósofo latinoamericano Carlos Pereda cuando le hace decir «Hacia la paz, perpetuamente». La paz, en resumidas cuentas, no es un factum, sino un proceso in fieri.

Nuestro segundo ejemplo sería el de la justicia. O, si lo preferimos, la Justicia en cuanto diferente del Derecho como institución. A diferencia del Derecho, que es un hecho institucional - el «hecho del Derecho» del que hablan libros como Law as Fact («El Derecho como hecho») de Olivecrona (o, a su modo, Faktizität und Geltung, «Facticidad y validez jurídicas», de Habermas) - , la naturaleza de la Justicia tampoco es fáctica sino utópica. Cuando le preguntaron a un poeta - habida cuenta de que las utopías, como la línea del horizonte cuando caminamos, mantienen imperturbable su distancia ante nuestros intentos de aproximación-que para qué servían entonces las utopías, nuestro poeta respondió, tan acertada como bellamente, que sirven «para hacernos caminar hacia adelante». Y, de análoga manera, a la pregunta «para qué sirve la Justicia» habría que responder que sirve para hacer avanzar al Derecho, es decir, para hacerlo más justo cada día. Un proceso cuya mejor ejemplificación la tendríamos, de unos siglos a esta parte, en la perseverancia de la lucha en pro de los derechos humanos, que antes de conquistados sólo eran «exigencias morales» acompañadas de la justa demanda de un «reconocimiento jurídico» hasta entonces negado por los tribunales. De donde la improcedencia de afirmar que «los jueces se encargan de impartir justicia» cuando lo que habría que decir en su lugar es que «se encargan de aplicar el Derecho vigente». Como también resulta improcedente hablar de Ministerios de Justicia cuando lo más correcto sería hacerlo de «Ministerios de Asuntos Jurídicos» u otra denominación más modesta de ese estilo.

Y tampoco la democracia, por proponer nuestro tercer y último ejemplo, sería un hecho sino que habría más bien que ver en ella otra utopía. O, por lo 
menos, eso es lo que sucede con lo que acostumbraba Aranguren a llamar la democracia como moral. Como sostenía ya en su obra Ética y política, la democracia como moral no es «democracia establecida», ni por ende primariamente una institución, porque lo establecido es lo hecho ya y no lo moral, es decir, lo que está aún por hacer y es todavía «exigencia incumplida». La «democracia como moral», por consiguiente, no será nunca érgon, un producto acabado, sino constitutivamente enérgeia. Y por eso Aranguren añadía que es más una aspiración que una posesión y hay que entenderla como «una conquista ético-política de cada día», que sólo a través de una autocrítica permanente podría ser mantenida. Para dejarle a él mismo la palabra, «la democracia es - como afirmaba Kant de la moral en general- una tarea infinita en la que, si no se progresa, se retrocede, pues incluso lo ya ganado ha de re-conquistarse nuevamente cada día».

Por lo demás, hay que cuidar en todos estos casos de no confundir - como nos recuerda Thomas McCarthy invocando las kantianas Ideas de la razón- los «ideales» con las «ilusiones», ni mucho menos con los proyectos disparatados y estrafalarios como el de aquel utopista decimonónico que pretendía transformar el agua de los océanos en limonada. Y, sobre todo, habría que saber combinar dosificadamente la perspectiva de la idealidad utópica con el aquí y ahora de la realidad - the view from nowhere con the view from somewhere, por así decirlo - si se quiere dotar a nuestra lucha por los ideales de una mínima eficacia. Sin olvidar que, en lo que a mí concierne cuando menos, habría que declarar a este respecto la preferencia por la "vía negativa» - en la que creo coincidir con ese gran maestro que es el filósofo mexicano Luis Villoro- consistente en luchar por ideales como la paz, la justicia o la democracia «jugando a la contra», es decir, oponiéndonos a las guerras, tratando de erradicar las injusticias y rebelándonos contra las tiranías... a sabiendas de que - si por ventura un día llegaran a instaurarse en este mundo una paz, una justicia y una democracia ampliamente extendidas y medianamente estables - nada habría a pesar de ello capaz de conjurar los retrocesos, el retorno de la humanidad a la barbarie y su despeño en la disutopía.

Y ha llegado la hora de abordar, siquiera sea muy comprimidamente puesto que no queda ya margen para más, nuestro tercer y último capítulo de la metafísica (de la) moral, en el que - trascendidos los dos interrogantes anteriores relativos a la realidad y la posibilidad - sólo nos resta preguntarnos por el sentido de ambos, así como del propio preguntar, levantando nuestra mirada y abismándola en una metafísica de lejanías dentro de la cual los perfiles antes más o menos nítidos comienzan a difuminarse y tornarse borrosos, enfrentándonos finalmente a lo que dimos en llamar con Aranguren la pregunta sin respuesta.

Como anunciamos en su momento, Aranguren llamaba así — «preguntas sin respuesta»- a las preguntas últimas de la metafisica que los metafísicos profesionales se empeñan inútilmente en contestar mediante fórmulas este- 
reotipadas que nunca acaban de satisfacernos. Pensemos, por ejemplo, en las tres clásicas preguntas «¿De dónde venimos, qué somos, adónde vamos?», preguntas que un filósofo materialista (y, por lo tanto, un metafísico) podría tratar de responder por medio de la fórmula «Venimos de la materia, somos materia y vamos a la materia», a lo que cabría sin duda replicar « $i Y$ todo eso para qué? (O, lo que viene a ser lo mismo, ¿Qué sentido tiene?)», puesto que - como Wittgenstein supo ver bien- las «preguntas por el sentido de la vida» (que es lo que son todas las anteriores) resultan de algún modo «preguntas recursivas», esto es, preguntas que recursivamente vendrían a generar nuevas preguntas de esa índole. Y si lo que el materialista (el metafísico materialista, repitámoslo) deseaba no era otra pregunta sino una respuesta contundente, materialistamente contundente, mejor hubiera hecho haciendo caso a Woody Allen, para quien la pregunta decisivamente relevante no sería ninguna de aquellas tres («¿De dónde venimos, qué somos, adónde vamos?») sino una cuarta pregunta, a saber, la a su vez más materialista «¿Qué hay esta noche para cenar?», que sin duda no daría ya lugar a repreguntas. Y otro tanto vendría a ocurrir con el metafísico idealista que respondiese a nuestra tríada con un «Venimos del espíritu, somos espíritu y vamos al espíritu», a lo que el Woody Allen de turno respondería a su vez que «Buen viaje y no se olvide de hacer una parada en la consulta del psicoanalista». Las preguntas más metafísicas de entre las metafísicas, las «preguntas de tercer grado» como cabría tal vez llamarlas, son, pues, difíciles de responder, como bien lo sabía el dibujante Máximo de El País en un chiste de hace unos cuantos años: en la viñeta un sabio (con cierto parecido a Sigmund Freud) le dice a otro que «no sabemos de dónde venimos, ni qué somos, ni adónde vamos», a lo que el segundo le replica «Si lo supiéramos, nos darían el Premio Nobel de Metafísica»...

Pero lo cierto es que, sin necesidad de aspirar a ningún premio, tales preguntas nos acucian y - quien más o quien menos - todos aventuramos para ellas, ya que no respuestas contundentes, al menos sí de vez en cuando «conjeturas», esto es, esbozos conjeturales de respuesta. El propio Aranguren, sin ir más lejos, no se privó de hacerlo así (a este nivel de la metafísica moral en el que se adivina que las respuestas a las preguntas sin respuesta no podrán por su parte ser sino preguntas) cuando se preguntaba quién poseería la clave del «sentido de la vida» $y$, más concretamente, del sentido de «nuestra» vida, es decir, de «la vida de cada uno» de nosotros. «¿A quién pedir» — se preguntaba Aranguren - «esa última comprensión que consista no tanto en juzgarnos cuanto en revelarnos quiénes somos y, por lo pronto, quién soy?», a lo que se «respondía» (entre inevitables comillas) lo siguiente: «No lo sé (aunque aventuro que) tal vez le corresponda darla (aquella última comprensión) a la Deidad ante la cual hayamos existido, siquiera como sueño, de suerte que - si la vida fuera sueño - sea, haya sido, esté siendo, vaya a ser sueño de Dios...». Pero cuando (en una larga entrevista publicada en 1993 y reproducida con posterioridad en diversos lugares, entre ellos el número monográfico 
que le dedicó tras su muerte, tres años más tarde, la revista Isegoría bajo el título de «Adiós a Aranguren») le pregunté a mi vez si, a tenor de la afirmación antes referida, cabría acaso suponer que hay «otra» vida además de «ésta», Aranguren me contestó: «Tampoco lo sé. Si me tienta pensar en ello es, más que nada, por la posibilidad de seguirla compartiendo con los seres queridos. Pero habría que dejarlo, me parece, en puntos suspensivos». Y como yo volviese a preguntarle: «¿Lo dejamos en puntos suspensivos?», me volvió a contestar: «Dejémoslo en puntos suspensivos...»; y, según recuerdo haber relatado en algún sitio, en ese momento - imprevistamente - la cinta de la grabadora se agotó y, en lugar de recambiarla, los dos de común acuerdo decidimos dar la entrevista por concluida.

Cuando Aranguren murió en 1996, la anécdota de «los puntos suspensivos» circuló con una cierta profusión. Y yo mismo me he referido alguna vez a los puntos suspensivos creyendo ver en ellos «una buena metáfora» de la frontera que separa a la creencia religiosa y la increencia, para lo cual es desde luego necesario que los interpretemos bien. Como increyente, por mi parte, yo nunca tuve dudas de que Aranguren era un creyente y de que eso nos separaba a uno del otro, sin merma alguna, por descontado, de nuestra mutua amistad. Pero, con ocasión de su muerte, un intérprete un tanto obtuso de su pensamiento dio en decir que la fórmula de los puntos suspensivos acreditaba «el escepticismo religioso de Aranguren» (el intérprete de marras resultó ser un clérigo integrista $\mathrm{y}$, como corresponde, más bien cerril), cuando lo cierto es que para Aranguren el escepticismo en cuestiones de esa índole se asemejaba más bien a un dogmatismo de signo inverso y sólo habría aceptado ser tenido por escéptico en la acepción de Juan de Mairena, a quien de nuevo Antonio Machado le hacía decir que - puestos a ser escépticos- habría que serlo tan radicalmente que llegáramos a ser escépticos (incluso) del propio escepticismo. Y, en cuanto a los puntos suspensivos, me atrevería a decir que - como cualquier otra frontera- los puntos suspensivos «unen al menos tanto cuanto separan» a los creyentes religiosos y a quienes no lo somos.

En mi opinión, la demanda de «sentido» - de un sentido «absoluto» o un «último» sentido, personal o colectivo, de nuestras respectivas vidas- es todavía más acuciante, y más universalmente compartida por los seres humanos, que la demanda misma de inmortalidad, de suerte que, incluso convertidos en despojos, los seres humanos perseverarán en esa exigencia de sentido y, como escribiría Quevedo, «serán ceniza, mas tendrá sentido» o aspirarán al menos a tenerlo. En cuanto a la demanda de inmortalidad, Unamuno la basaba, como es bien conocido, en el imperativo de Sénancour que reza «Hagamos que la nada, si es que nos está reservada, sea injusta». Pero no a todo el mundo, y desde luego no a un increyente, tendría por qué parecerle eso - la nada - una injusticia, por más que pueda lamentarlo y hasta desesperarle. En cambio, lo que difícilmente resisten los seres humanos, ni individual ni socialmente, es que sus alegrías al igual que sus sufrimientos, sus éxitos al igual 
que sus fracasos, sus afectos al igual que sus desafectos, «no signifiquen algo para alguien además de uno mismo», es decir, comenzando por uno mismo pero trascendiendo ese ámbito egocéntrico y abriéndose al «otro» o a los «otros». Una trascendencia, en fin, que el creyente prolongará hasta el infinitamente «Otro» $\mathrm{u}$ «Otro» infinitamente trascendente.

Y ese sentido de la vida que demandan los individuos lo demandan también las sociedades, transformándolo así en «sentido de la historia». Esto es, en exigencia de que esa historia, al igual que la vida misma, no sea «un cuento narrado por un idiota con gran aparato y que nada significa» como lo acabó siendo según Shakesperare para Macbeth, sino consista en un relato dotado de algún sentido aunque sea entrevisto oscuramente. Un relato que, para el creyente, adquiriría la plenitud de su sentido cuando tuviera por narrador a Dios - el infinitamente Otro de que hablábamos-y éste, en su ensueño, congregue cabe sí a todas sus criaturas, produciéndose de este modo en su seno la apocatástasis paulina o reconciliación final de la Creación con su Creador. Pero no se crea que las cosas son en definitiva tan distintas para el increyente, y ahí está como prueba ese soberbio texto de un increyente - e incluso de un ateo o, cuando menos, un agnóstico como lo era sin duda Max Horkheimer, el padre de la Escuela de Francfort—, texto asimismo plasmado en una entrevista con Hans Gumnior bajo el título de Die Sehnsucht nach dem ganz Anderen, es decir, «El anhelo (pero no menos la nostalgia, pues de ambas maneras admitiría ser traducida la palabra alemana Sehnsucht) de lo totalmente Otro».

Un Otro o un Absoluto que se dejaría hoy acoger bajo diversas manifestaciones tras «la muerte de Dios» con la Modernidad, como, por citar un ejemplo señalado, la de un Arte cuyo objeto no sea tanto «la belleza» cuanto lo que llamara Kant «lo sublime», algo que puede en ocasiones originar malentendidos - así, cuando se da ese paso que a menudo lo separa de «lo ridículo»- pero que cabría en sí mismo interpretar como una versión inmanente o intramundana de aquel Absoluto al que, desde remotos tiempos hasta tiempos no tan remotos, se le ha venido rindiendo un culto reconocidamente religioso.

Hasta aquí, pues, se extienden los confines de lo que hemos dado en llamar «el horizonte metafísico de la ética», quizás indiscernible, como también lo quería Wittgenstein, de la estética no menos que de la religión.

\section{6. Ética, metafísica y «preguntas sin respuesta»}

En su libro ya citado sobre La comunicación humana, Aranguren hacía balance (y perspectiva) de su aproximación a la metafísica — con la ética por trasfondo - desde una perspectiva semiótica difusa que la avecina por igual a la poesía que a la teología: «¿Qué pasa entonces con la metafísica? ¿Es que carecen sus proposiciones de sentido, como aseguraban los neopositivistas? 
No. Lo que pasa es que, en sí mismas, son preguntas que carecen de respuesta. Son como un S.O.S. que no obtuviera contestación... Se ha dicho reiteradas veces que, en el arte, lo comunicado es la comunicación. Paralelamente habría que decir que, en la metafísica, lo comunicado es puramente la pregunta. ¿Significa esto que la metafísica es imposible? Tampoco. Significa solamente que es problemática».

Como lo explicita el subtítulo de un iluminador «libro de claves» del asunto - La metafísica, de José Luis Pardo (2006) - , la metafísica se ocupa de «preguntas sin respuesta y problemas sin solución»... que, sin embargo, no podemos «dejar de plantearnos incesantemente».

$Y$ ya que hace bien poco hemos vuelto a encontrarnos con un Wittgenstein que ha estado tan presente a lo largo y lo ancho de este texto, me gustaría poder concluirlo con unas citas suyas, concretamente tres, que me limitaré a reproducir con su correspondiente cronología.

La primera procede del Tractatus de 1922 (parágrafo 6.52): «Sentimos que, aun cuando todas las posibles preguntas de la ciencia hubieran obtenido una respuesta, los problemas de nuestra vida ni siquiera habrían sido tocados. Desde luego, entonces ya no quedaría pregunta alguna, y esto es precisamente la respuesta».

La segunda lo hace de las póstumas Investigaciones de 1953 (§ 118): «¿De dónde le viene su importancia a nuestra indagación, puesto que al parecer no hace otra cosa que destruir todo lo que tiene interés, es decir, todo lo grande e importante? (Destruir todos los edificios, dejando tras de sí tan sólo trozos de piedra y escombros). Pero lo que estamos destruyendo no son sino castillos en el aire y nos estamos limitando a despejar el piso del lenguaje sobre el que se sustentan».

Y la tercera, en fin, la extraigo de una obra a mitad de camino entre las dos anteriores, como lo es la célebre Conferencia sobre ética de 1930, la única conferencia que Wittgenstein dio en su vida y el único escrito en el que expresamente se ocupó de la ética, relacionándola con lo que da en llamar «los límites del lenguaje» (que, como ya sabemos, son «los límites de la razón») y acerca de los cuales escribe como sigue: «Mi único propósito - y creo que el de todos aquellos que han tratado alguna vez de escribir o de hablar de ética o religión - es el de arremeter contra los límites del lenguaje. Semejante arremeter contra las paredes de nuestra jaula constituye un empeño perfecta y absolutamente desesperanzado. La ética, en la medida en que surge del deseo de decir algo sobre el sentido último de la vida, sobre lo absolutamente bueno o lo absolutamente valioso, no puede ser una ciencia. Pero es un testimonio de una tendencia del espíritu humano que yo personalmente no puedo sino respetar profundamente y que por nada del mundo ridiculizaría».

No voy a tratar aquí de interpretar, ni para mis oyentes ni para mis lectores, esos pasajes, sino que se los dejo para que mediten sobre ellos. Como he tratado machaconamente de recordar en nuestro último capítulo de la metafí- 
sica (de la) moral, lo importante de su cifra es siempre el signo de interrogación. Y, generalizando, lo importante de la filosofía no estriba nunca tanto en responder a sus interrogantes cuando en dejárnoslos abiertos $\mathrm{y}$, a través de ellos, darnos precisamente que pensar...

\section{REFERENCIAS BIBLIOGRÁFICAS}

AlBerT, H., Konstruktion und Kritik. Aufsätze zur Philosophie des kritischen Rationalismus, Hamburgo, 1982.

APEL, K.-O., Transformation der Philosophie, 2 vols., Francfort del Main, 1973 (hay trad. cast. de A. Cortina, J. Chamorro y J. Conill, La transformación de la filosofia, 2 vols., Madrid, 1985).

- Diskurs und Verantwortung. Das Problem des Übergang zur postkonventionelle Moral, Francfort del Main, 1988.

APEL, K.-O. y otros (eds.), Ética comunicativa y democracia, Barcelona, 1991.

Aramayo, R. R., Crítica de la razón ucrónica (Prólogo de J. Muguerza), Madrid, 1992.

Aranguren, J. L. L., Ética, Madrid, 1958 (recogida en Obras completas, ed. Feliciano Blázquez, 6 volúmenes, Madrid, 1994-97, vol. II.).

—Ética y política, Madrid, 1963 (Obras completas, vol. III).

- Lo que sabemos de moral, Madrid, 1967; reeditada como Propuestas morales, Madrid, 1983 (Obras completas, vol. II).

- La comunicación humana, Madrid, 1967 (Obras completas, vol. V).

- La democracia establecida: una crítica intelectual, Madrid, 1978 (Obras completas, vol. V).

Arendt, H., Lectures on Kant's Political Philosophy, ed. E. Beiner, Chicago, 1982 (hay trad. cast. de C. Corral, La filosofía politica de Kant, Barcelona, 2003).

Austin, J. L., How to do Things with Words, Oxford, 1962 (hay trad. cast. de G. R. Carrió y E. A. Rabossi, Cómo hacer cosas con palabras, Buenos Aires-Barcelona, 1971).

Ayer, A. J., Language, Truth and Logic, Londres, 1936 (hay trad. cast. de R. Resta, Lenguaje, verdad y lógica, Buenos Aires, 1965).

Bergmann, G., The Metaphysics of Logical Positivism, Madison-Milwaukee-Londres, 1967.

Bloch, E., Geist der Utopie, en Gesamtausgabe, vol. I, Francfort del Main, 1959.

- Das Prinzip Hoffnung, en Gesamtausgabe, vols. V/1 y V/2, Francfort del Main, 1963 (hay trad. cast. de F. González Vicén, El principio esperanza, 3 vols., Madrid, 1977; reed. al cuidado de F. Sierra, Madrid, 2004-2007).

Bonete, E., Aranguren: la ética entre la religión y la política, Madrid, 1989.

Brandom, R. B., Articulating Reasons. An Introduction to Inferentialism, Cambridge, Mass., 2000 (hay trad. cast. de L. Martínez, La articulación de las razones, Madrid, 2002).

CAMPs, V., La imaginación ética, Barcelona, 1983.

CAMPS, V. (ed.), Historia de la ética, 3 vols., Barcelona, 1988-89.

Camps, V. y Valcárcel, A., Hablemos de Dios, Madrid, 2007.

CAndel, M., Metafisica de cercanías, Madrid-Barcelona, 2004. 
Cela Conde, C. J. y Ayala, F. J., Senderos de la evolución humana, Madrid, 2001.

Cerezo, P., «El giro kantiano en la ética de José Luis L. Aranguren», Isegoría, 15, 1997 (Adiós a Aranguren), pp. 127-44.

- Reivindicación del diálogo, Madrid, 1997.

Cerezo, P. y Muguerza, J. (eds.), La filosofía hoy, Barcelona, 2000.

Collingwood, R. G., An Eassy on Metaphysics, Oxford, 1940; ed. revisada por Rex Martin, 1998 (hay trad. cast. parcial en P. Badillo O'Farrell y E. Bocardo Crespo, eds., R. G. Collingwood: Historia, Metafísica y Política. Ensayos e interpretaciones, Sevilla, 2005).

CortinA, A., Razón comunicativa y responsabilidad solidaria (Epílogo de K.-O. Apel), Salamanca, 1985.

- Ética mínima. Introducción a la filosofía práctica (Prólogo de J. L. Aranguren), Madrid, 1986.

- Crítica y utopía: la Escuela de Frankfurt (Prólogo de J. Muguerza), Madrid, 1985.

DíAZ, E., Los viejos maestros. La reconstrucción de la razón, Madrid, 1994.

FERNÁNDEZ GARCíA, E., «La moralización de la política por medio del Estado de Derecho», en E.F.G., Valores constitucionales y Derecho, Madrid, 2009, pp. 17-28.

FERrATER Mora, J., La filosofía en el mundo de hoy, 2. a ed., 1963 (versión castellana de Philosophy Today: Conflicting Tendencies in Contemporary Thought, Nueva York, 1960).

FRAIJÓ, M., «El cristianismo ante el enigma del mal (Carta a un amigo increyente)», en M. Fraijó, Dios, el mal y otros ensayos, Madrid, 2004, pp. 23-74.

Fraijó, M. (ed.), Filosofía de la religión. Estudios y textos, Madrid, 1994.

Garzón VAldés, E., Calamidades, Barcelona, 2004.

Gazzaniga, M., The Ethical Brain, Nueva York, 2005 (hay trad. cast. de M. Pino Moreno, El cerebro ético, Barcelona, 2006).

Giusti, M., Alas y raíces (Ensayos sobre ética y modernidad), Lima, 1999.

Gomá, J., Imitación y experiencia (Presentación de J. Muguerza), Valencia, 2003.

GómEz, C., «Ética y Utopía», en C. Gómez y J. Muguerza (eds.), La aventura de la moralidad (Paradigmas, fronteras y problemas de la ética), Madrid, 2007 (3. a ed. 2009), pp. 480-509.

Gómez, C. (ed.), Doce textos fundamentales de la Ética del siglo XX, Madrid, 2002.

Gómez Caffarena, J., El teísmo moral en Kant, Madrid, 1983.

Gómez Pin, V., El hombre, un animal singular, Madrid, 2006.

GonzÁlez Valenzuela, J., Genoma humano y dignidad humana, Barcelona-México, 2005.

HABERMAS, J., Theorie des kommunikativen Handelns, 2 vols., Francfort del Main, 1981 (hay trad. cast. de M. Jiménez Redondo, Teoría de la acción comunicativa, Madrid, 1987).

- Moralbewusstsein und kommunikatives Handeln, Francfort del Main, 1983 (hay trad. cast. de R. García Cotarelo, Conciencia moral y acción comunicativa, 1985).

- Erläuterungen zur Diskursethik, Francfort del Main, 1991 (hay trad. cast. de J. Mardomingo, Aclaraciones a la ética del discurso, Madrid, 2000).

- Nachmetaphysisches Denken. Philosophische Aufsätze, Francfort del Main, 1988 (hay trad. cast. de M. Jiménez Redondo, Pensamiento postmetafísico. Ensayos filosóficos, Madrid, 1990). 
Hauser, M. D., Moral Minds, Nueva York, 2006 (hay trad. cast. de M. Candel, La mente moral, Barcelona, 2008).

Horkheimer, M. y Gumnior, H., Die Sehnsucht nach dem ganz Anderen, Hamburgo, 1970 (hay trad. cast. de A. Ortiz-Osés, ed., A la búsqueda del sentido, Salamanca, 1976).

Imaz, E., Topía y Utopía, México, 1946 (reedición de J. A. Ascunce, San Sebastián, 1989).

Kant, I., Kritik der reinen Vernunft (1781-1787), AK III, IV (hay trad. cast. de P. Ribas, Crítica de la razón pura, Madrid, 1978).

- Prolegomena zu einer jeden künftigen Metaphysik, die als Wissenschaft wird auftreten können (1783), AK IV (hay trad. cast. de M. Caimi, Prolegómenos, Buenos Aires, 1984).

- Grundlegung zur Metaphysik der Sitten (1785), AK IV (hay trad. cast. de M. García Morente, Fundamentación de la metafísica de las costumbres, Madrid, 1921; y también de R. R. Aramayo, Madrid, 2002).

- Kritik der praktischen Vernunft (1788), AK V (hay trad. cast. de M. García Morente, Crítica de la razón práctica, Madrid, 1913; y también de R. Rodríguez Aramayo, Madrid, 2000).

- Kritik der Urteilskraft (1790), AK V (hay trad. cast. de M. García Morente, Crítica del juicio, Madrid, 1914; y también de R. R. Aramayo y S. Mas, Crítica del discernimiento, Madrid, 2003).

- Die Metaphysik der Sitten (1797), AK VI (hay trad. cast. de A. Cortina y J. Conill, La metafísica de las costumbres, Madrid, 1989).

- Beantwortung der Frage: Was ist Aufklärung? (1784), AK VIII (hay trad. cast. de E. Estiú, «Respuesta a la pregunta ¿Qué es la Ilustración?», en Filosofía de la Historia, Buenos Aires, 1964; y también de R. Rodríguez Aramayo, ¿Qué es la Ilustración? y otros escritos de ética, política y filosofía de la historia, Madrid, 2004).

- Zum ewigen Frieden (1795), AK VIII (hay trad. cast., entre otros, de J. Muñoz, La paz perpetua, Madrid, 1999).

Kneale, W. y M., The Development of Logic, Oxford, 5. ${ }^{\text {e ed., }} 1971$ (hay trad. cast. de J. Muguerza, El desarrollo de la lógica, Madrid, 1973).

LAFOnT, C., Sprache und Welterschliessung. Zur linguistischen Wende der Hermeneutik Heideggers, Francfort del Main, 1994 (hay trad. cast. de P. Fabra i Abat, Lenguaje y apertura del mundo. El giro lingüistico de la hermeneútica de Heidegger, Madrid, 1997).

MacInTyre, A., Three Rival Versions of Moral Enquiry. Encyclopaedia, Genealogy and Tradition, Nueva York, 1990 (hay trad. cast. de R. Rovira, Tres versiones rivales de la ética, Madrid, 1992).

MCCARTHY, T., Ideals and Illusions. On Reconstruction and Deconstruction in Contemporary Critical Theory, Cambridge, Mass., 1991 (hay trad. cast. de A. Rivero, Ideales e ilusiones, Madrid, 1992).

McDowell, J., Mind, Value and Reality, Cambridge, Mass.-Londres, 1998 (2. ' ed., 2002).

Machado, A., Juan de Mairena (ed. A. Fernández Ferrer, Cátedra), 2 vols., Madrid, 1986.

Mosterín, J., La naturaleza humana, Madrid, 2005. 
MuguerzA, J., «Esplendor y miseria del análisis filosófico», en J. Muguerza (ed.), La concepción analítica de la filosofía, Madrid, 1974 (4. ${ }^{\mathrm{a}}$ ed. 1986), pp. 15-138.

- «La crisis de la filosofía analítica de la ciencia», en J. Muguerza (ed.), Panorama de la filosofía contemporánea de la ciencia, Madrid, 1977, pp. 7-45.

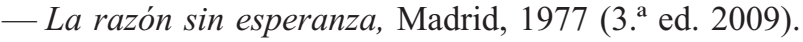

— «Kant y el sueño de la razón», en C. Thiebaut (ed.), La herencia ética de la Ilustración, Barcelona, 1991, pp. 9-36.

- Desde la perplejidad, Madrid-México-Buenos Aires, 1990 (4. ${ }^{\text {a }}$ ed. 2006).

- «Wittgenstein. Las voces éticas del silencio» en C. Castilla del Pino (ed.), El silencio, Madrid, 1992, pp. 125-64.

— «Sobre la condición metafísica y/o postmetafísica del sujeto moral», en María Herrera (ed.), Jürgen Habermas: Moralidad, Ética y Política (Propuestas y Críticas), México, 1993, pp. 173-92.

- «Encuentro con José Luis L. Aranguren», en E. López Aranguren, J. Muguerza y J. M. Valverde, Retrato de José Luis Aranguren, Madrid, 1993, pp. 66-88 (reproducido en Isegoría, 15, 1997, Adiós a Aranguren, pp. 55-93).

— «Razonabilidad» en P. Cerezo Galán (ed.), Democracia y virtudes cívicas, Madrid, 2005, pp. 113-49.

— «En torno a la vigencia del pensamiento utópico», en R. R. Aramayo y T. Ausín (eds.), Valores e historia en la Europa del siglo XXI, Madrid-México, 2006, pp. 337-53.

Orsi, R., El saber del error. Filosofía y tragedia en Sófocles, Madrid, 2007.

OrTEga y GASSET, J., Ideas y creencias (1940), Obras completas (ed. Revista de

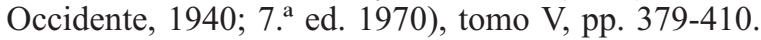

PARdo, J. L., La metafisica. Preguntas sin respuesta y problemas sin solución, Valencia, 2006.

PEREDA, C., «Sobre la consigna: hacia la paz perpetuamente», en R. R. Aramayo, J. Muguerza y C. Roldán (eds.), La paz y el ideal cosmopolita de la Ilustración (A propósito del bicentenario de «Hacia la paz perpetua» de Kant), Madrid, 1996, pp. 77-100.

Ramachandran, V. S., The Emerging Mind, Londres, 2003 (hay trad. cast. de F. Pardo, Los laberintos del cerebro, Barcelona, 2008).

Rawls, J., «The Idea of Public Reason Revisited», en Collected Papers, ed. S. Freeman, Cambridge, Mass., 1999, pp. 573-615 (hay trad. cast. de H. Valencia Villa, El derecho de gentes y "Una revisión de la idea de razón pública», Barcelona-Buenos Aires-México, 2001).

RHEEs, R., Without Answers, Oxford, 1975.

RHEEs, R. (ed.), Recollections of Wittgenstein, Oxford, 1984 (hay trad. cast. de R. Vargas, Recuerdos de Wittgenstein, México, 1989).

Rivera, J. A., Menos utopía y más libertad, Barcelona, 2001.

RóDEnAS, P., «Política, Poli(é)tica, Iuspoli(é)tica (En diálogo con Muguerza y Garzón Valdés)», en E. Garzón Valdés, J. Muguerza y T. Murphy (eds.), Democracia y cultura política (Los Encuentros de Canarias), Las Palmas, 2008, pp. 245-301.

RoDRíGUEZ-IBÁÑEZ, J. E., El sueño de la razón: la modernidad a la luz de la teoría social, Madrid, 1982.

Roldán, C., Entre Casandra y Clío. Una historia de la filosofía de la historia (Prólogo de J. Muguerza), Madrid, 1997. 
RORTY, R., «Metaphilosophical Difficulties of Linguistic Philosophy», Introducción a R. Rorty (ed.) The Linguistic Turn. Recent Essays on Philosophical Method, Chicago-Londres, 1967, pp. 1-40 (hay trad. cast. de G. Bello, El giro lingüístico, Barcelona, 1990).

- Contingency, Irony, and Solidarity, Cambridge-Nueva York, 1989 (hay trad. cast. de A. E. Sinnot, Contingencia, ironía y solidaridad, Barcelona, 1991).

- El pragmatismo, una versión (Antiautoritarismo en epistemología y ética), Lecciones impartidas en la «Cátedra Ferrater Mora de la Universidad de Girona», Barcelona, 2000.

RuBiA, F. J., El fantasma de la libertad, Barcelona, 2009.

RÜHLE, V. (ed.), «Einleitung» a Beiträge zur Philosophie aus Spanien, Friburgo-Munich, 1992, pp. 11-26.

SAVATER, F., Las preguntas de la vida, Barcelona, 1999.

SEarle, J. R., Speech Acts: an Essay in the Philosophy of Language, Cambridge, 1969 (hay trad. cast. de L. Valdés Villanueva, Actos de habla: ensayo de filosofía del lenguaje, Madrid, 1980).

TAYLOR, Ch., The Ethics of Authenticity, Cambridge, Mass., 1991 (hay trad. cast. de P. Carbajosa, La ética de la autenticidad, con introd. de C. Thiebaut, Barcelona, 1994).

Thiebaut, C., Los límites de la comunidad, Madrid, 1991.

ThieBaut, C. (ed.), La herencia ética de la Ilustración, Barcelona, 1992.

Toulmin, S., Return to Reason, Cambridge, Mass., 2001 (hay trad. cast. de I. González-Gallarza y T. Caballero, Regreso a la razón, Barcelona, 2001).

TríAs, E., Ética y condición humana, Barcelona, 2000.

Tugendhat, E., «Moral in evolutionstheoretischer Sicht», en Aufsätze 1992-2000, Francfort del Main, 2001, pp. 199-224 (hay trad. cast. de R. Cuartango y otros, Problemas, Barcelona, 2001).

- Anthropologie statt Metaphysik, Munich, 2007 (hay trad. cast. de D. Gamper y otros, Antropología en vez de metafísica, Barcelona, 2008).

Valdecantos, A., Contra el relativismo, Madrid, 1999.

VegA, L., Si de argumentar se trata, Madrid-Barcelona, 2003.

VILAR, G., La razón insatisfecha, Barcelona, 1999.

Villoro, L., Los retos de la sociedad por venir, México, 2007.

Waismann, F., Wittgenstein und der Wiener Kreis, Viena, 1947 (ed. inglesa de B. F. McGuinness, Oxford, 1967; hay trad. cast. de M. Arbolí, Ludwig Wittgenstein y el Círculo de Viena, México, 1973).

Wittgenstein, L., Logisch-philosophische Abhandlung - Tractatus logico-philosophicus, eds. C. K. Odgen y F. P. Ramsey, Londres, 1922 y D. F. Pears y B. F. McGuiness, Londres, 1961 (hay trad. cast. —Tractatus - de E. Tierno Galván, Madrid, 1957; de J. Muñoz e I. Reguera, Madrid, 1987; y de L. M. Valdés Villanueva, Madrid, 2002).

- Philosophische Untersuchungen - Philosophical Investigations, eds. G. E. M. Anscombe y R. Rhees, Oxford, 1953 y 1967 (hay trad. cast. de A. García Suárez y U. Moulines, Investigaciones filosóficas, México-Barcelona, 1988).

— «Wittgenstein's Lecture on Ethics (1930)», The Philosophical Review, 74, 1965, pp. 3-12 y ss. (hay trad. cast. de F. Birulés, introd. de M. Cruz, Conferencia sobre ética y otros textos, Barcelona-Buenos Aires-México, 1989). 
- Lectures and Conversations on Aesthetics, Psychology, and Religious Belief, ed. C. Barrett, Cambridge, 1966 (hay trad. cast. de I. Reguera, Lecciones y conversaciones sobre estética, psicología y creencia religiosa), Madrid, 1992.

Wittgenstein, L. y Bouwsma, O. K., Conversations 1949-1951, ed. J. L. Craft y R. E. Hustwitt, Austin, 1986 (hay trad. cast. de M. A. Quintana Paz, Últimas conversaciones, Salamanca, 2004).

Zamora Bonilla, J., Cuestión de protocolo. Ensayos de metodología de la ciencia, Madrid, 2005.

ŽıžEK, S., La suspensión política de la ética (trad. de M. Mayer), Buenos Aires, 2005. 